\title{
Morphological and sedimentological response of a mixed-energy barrier island tidal inlet to storm and failr-weather conditions
}

\author{
G. Herrling and C. Winter \\ MARUM - Center for Marine Environmental Sciences, University of Bremen, Bremen, Germany \\ Correspondence to: G. Herrling (gherrling@marum.de)
}

Received: 21 October 2013 - Published in Earth Surf. Dynam. Discuss.: 15 November 2013

Revised: 30 April 2014 - Accepted: 11 May 2014 - Published: 26 June 2014

\begin{abstract}
The environment of ebb-tidal deltas between barrier island systems is characterized by a complex morphology with ebb- and flood-dominated channels, shoals and swash bars connecting the ebb-tidal delta platform to the adjacent island. These morphological features reveal characteristic surface sediment grain-size distributions and are subject to a continuous adaptation to the prevailing hydrodynamic forces. The mixed-energy tidal inlet Otzumer Balje between the East Frisian barrier islands of Langeoog and Spiekeroog in the southern North Sea has been chosen here as a model study area for the identification of relevant hydrodynamic drivers of morphology and sedimentology. We compare the effect of high-energy, wave-dominated storm conditions to mid-term, tide-dominated fair-weather conditions on tidal inlet morphology and sedimentology with a processbased numerical model. A multi-fractional approach with five grain-size fractions between 150 and $450 \mu \mathrm{m}$ allows for the simulation of corresponding surface sediment grain-size distributions. Net sediment fluxes for distinct conditions are identified: during storm conditions, bed load sediment transport is generally onshore directed on the shallower ebb-tidal delta shoals, whereas fine-grained suspended sediment bypasses the tidal inlet by wave-driven currents. During fair weather the sediment transport mainly focuses on the inlet throat and the marginal flood channels. We show how the observed sediment grain-size distribution and the morphological response at mixed-energy tidal inlets are the result of both wave-dominated less frequent storm conditions and mid-term, tide-dominant fair-weather conditions.
\end{abstract}

\section{Introduction}

Tidal inlets at barrier island systems connect the open sea with the back-barrier tidal basin. Typically, they feature an ebb-tidal delta seawards and a flood-tidal delta landwards of a deep inlet throat that is bordered by shallow sandy shoals and marginal flood channels (Hayes, 1979). Both tidal flow constriction through the narrow inlet and wave energy dissipation on depth-limited ebb-tidal delta shoals account for local enhanced sediment transport and rapid morphological evolution.

Morphodynamics at mixed-energy tidal inlets are driven by the combined action of waves and tides and the relative contribution of these interacting forces largely determines the morphological and sedimentological response. Ko- mar (1996), De Swart and Zimmermann (2009), Davis and FitzGerald (2009) and FitzGerald et al. (2012) give recent and comprehensive reviews on morphodynamic processes at a large variety of tidal inlet systems. The early work of Hayes $(1975,1979)$ and a recent study applying processbased models (Nahon et al., 2012) classified mixed-energy inlet regimes in a range between tide-dominated and wavedominated and suggested corresponding inlet geometries that are in equilibrium with the long-term energetic input from waves and/or tides. Sha and Van den Berg (1993) developed a descriptive model to explain ebb-tidal delta symmetry, i.e., the orientation of the seaward inlet channel with respect to shallow ebb-delta shoals, as a response to the relative direction of waves to the interplay of tidal currents alongshore and within the inlet. Very few studies at mixed-energy 
tidal inlets have investigated the complex interaction of tideand wave-driven processes and distinguished the contribution of each agent to residual sediment fluxes and morphological changes (e.g., Bertin et al., 2009; Elias and Hansen, 2013; Elias et al., 2006; Sha, 1989). Even fewer studies have managed to relate observed distributions of surface sediment grain sizes at tidal inlet systems to distinct physical drivers (e.g., Sha, 1990; van Lancker et al., 2004).

Recent studies have shown the applicability of processbased numerical models for sedimentological studies, for example, to simulate surface sediment grain-size distributions in combination with morphological changes (Kwoll and Winter, 2011; Van der Wegen et al., 2011a, b). This suggests the application of multi-grain-size models to decipher the morphological and sedimentological effect of different hydrodynamic drivers, i.e., different model boundary conditions.

In this study we aim to investigate the effect of tide- and wave dominance on residual sediment pathways at a mixedenergy barrier island tidal inlet Otzumer Balje in the southern North Sea. It serves as an example of a mixed-energy, slightly tide-dominant inlet regime with similar characteristics as described, for example, by Hayes (1979). This is achieved by simulating a storm event that represents a period of wave dominance and fair-weather conditions with waves smaller than average representing tide-dominated conditions. Real-time data of tides, wind and waves are applied as forcing conditions for each model scenario, and are assumed to be sufficiently representative to study the morphological and sedimentological responses to low- and high-energetic conditions. The following characteristics of tidal inlet systems are investigated:

1. It is commonly understood that ebb-tidal delta erosion during episodic storm events counteracts the continuous replenishment of the ebb-tidal delta during tidedominated fair-weather conditions (De Swart and Zimmerman, 2009). We aim to show how this dynamic equilibrium behavior of either wave- or tide-dominated forcing conditions determines the sedimentology and morphology at a typical mixed-energy tidal inlet and the adjacent foreshore. After a synthetic separation of tideand wave-dominated forcing conditions, we will point out relevant morphodynamics and sediment pathways that are due to the interaction of the driving forces leading to, for example, elongated channel fill deposits at the margin of the tidal inlet throat.

2. Son et al. (2010) postulated a dominant circular sediment pathway at the eastern ebb-tidal delta platform of the tidal inlet Otzumer Balje investigated here. Sediments are thought to be recycled between the ebb-tidal delta and the inlet throat without any evidence of sediment bypass to the downdrift beach. For the Dutch Ameland tidal inlet, authors have mentioned recirculation cells at the downdrift shoals of the ebb-tidal delta supporting reversed net sediment transports towards the inlet throat, but claim only minor significance with respect to the overall sediment dynamics (Cheung et al., 2007; Elias et al., 2006; Sha, 1989). We evaluate the relevance of this recirculation cell at mixed-energy tidal inlets and identify the hydrodynamic drivers and interrelated mechanisms that induce these net circular sediment fluxes.

\section{Study area}

The tidal inlet Otzumer Balje is located between the East Frisian barrier islands Langeoog and Spiekeroog in the southern North Sea (Fig. 1). The back-barrier tidal basin represents a drainage channel system typical for the Wadden Sea. According to the classification of Hayes $(1975,1979)$, the study area is mesotidal with a mixed-energy to slightly tide-dominated regime. The tide is semidiurnal with a mean range of $2.8 \mathrm{~m}$ at Spiekeroog. The gorge in the inlet throat reaches maximum depths of approximately $24 \mathrm{~m}$ below German datum (around mean sea level) and a width of approximately $1 \mathrm{~km}$. The residual flow in the inlet throat is ebbdominant with maximum current velocities for neap to spring tides ranging from 0.5 to 1.0 and 0.8 to $1.6 \mathrm{~m} \mathrm{~s}^{-1}$ for flood and ebb tide, respectively (Bartholomä et al., 2009).

Mean wind directions are from the westerly sector with mean velocities of about $7 \mathrm{~m} \mathrm{~s}^{-1}$ observed at the offshore platform FINO1 at approx. $40 \mathrm{~km}$ off the East Frisian barrier islands. Here, mean significant wave heights of $1.4 \mathrm{~m}$ and mean peak periods of $6.9 \mathrm{~s}$ have been measured (data from May 2004 to June 2006, Federal Ministry for Environment, Nature Conservation and Nuclear Safety (BMU) and the Project Management Jülich (PTJ)). Extreme storms from the northwesterly sector can generate surge water levels of up to 2.5 to $3.3 \mathrm{~m}$ above mean high water at the coast. During the extreme storm event on 9 November 2007, known as "Tilo", significant wave heights of $10 \mathrm{~m}$, maximum wave heights of $17 \mathrm{~m}$ and peak periods of up to $15 \mathrm{~s}$ were measured offshore at water depths of $30 \mathrm{~m}$ at the research platform FINO1 (Outzen et al., 2008). The combination of a tidal wave that travels from west to east and the dominant westerly wind and wave directions generates an alongshore eastward-directed net sediment drift. FitzGerald et al. (1984) estimated the net transport rate to be about $270000 \mathrm{~m}^{3} \mathrm{yr}^{-1}$ of sand.

The inlet consists of a variety of morphological features such as ebb- and flood-tidal deltas, inlet throat and marginal flood channels bordered by shoals and swash bars. The latter are sand bars with dimensions on the order of a few hundred meters superimposed onto the ebb-tidal delta that migrate onshore and coalesce to larger intertidal bar systems in the vicinity of the shore (FitzGerald, 1982); it should be mentioned at this point that the nomenclature "swash bars" is commonly used but is rather misleading as the physical processes involved are miscellaneous and not primarily related 


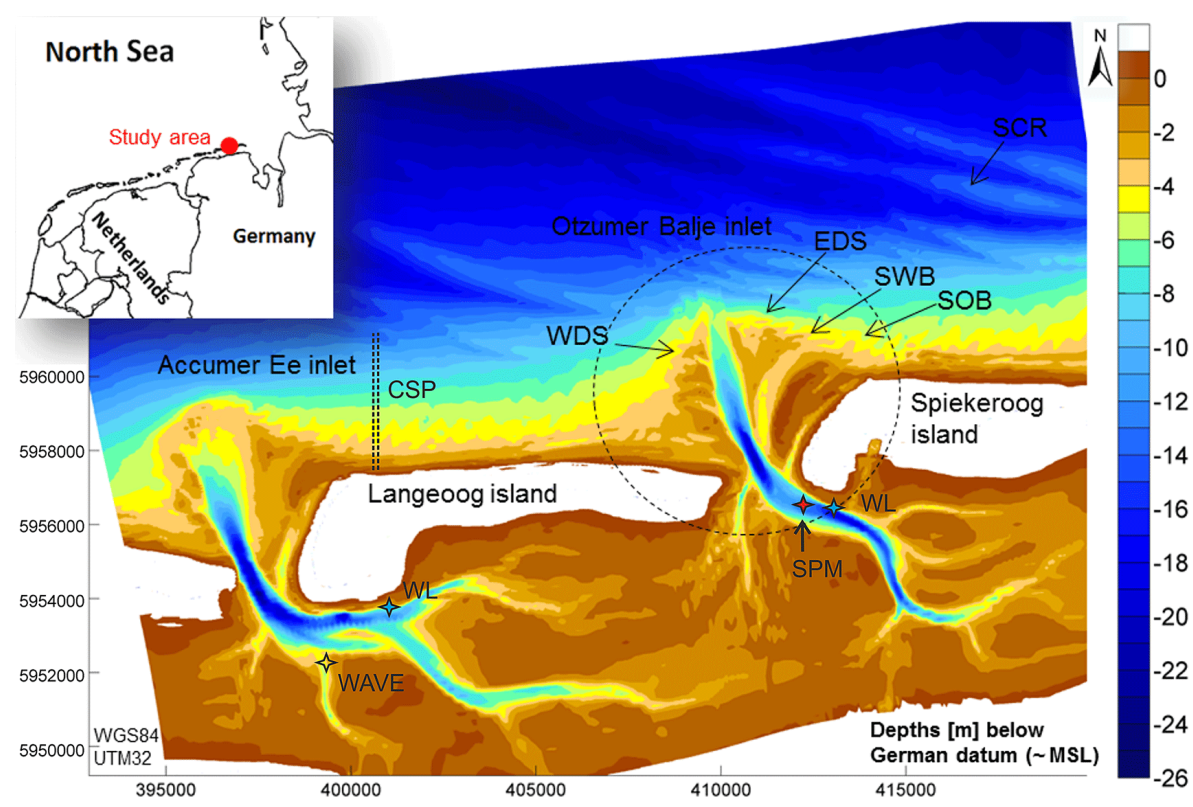

Figure 1. East Frisian barrier island system in the southern North Sea with the study area Otzumer Balje inlet between the islands Langeoog and Spiekeroog and nearshore morphological features such as the western/eastern ebb-tidal delta shoals (WDS/EDS), swash bars (SWB), shore-oblique sand bars (SOB) and shoreface-connected ridges (SCR). Measurement positions are indicated by wave (WAVE), water level (WL), suspended matter (SPM) and bathymetry at cross-shore profiles (CSP).

to swash. At the ebb-tidal delta of the Otzumer Balje inlet, their orientation is more shore-parallel compared to the shore-oblique sand bars that emerge downdrift of the ebbtidal delta. The bed of the tidal inlet reveals different bed forms, from ripples to dunes. In the inlet throat, Noormets et al. (2006) measured three-dimensional sand dunes with mean lengths of $7.5 \mathrm{~m}$ and mean heights of $0.35 \mathrm{~m}$. Medium to coarse, poorly sorted sands are found in the inlet channel; the ebb-tidal delta body mainly consists of fine sand but is superimposed by swash bars of medium-sized sand (Son et al., 2010).

\section{Methodology}

\subsection{Modeling system}

The modeling system Delft3D (Deltares, 2011) has been applied to set up and run high-resolution process-based morphodynamic models. The mathematical model solves the three-dimensional shallow-water equations and continuity equation on a staggered model grid by means of an implicit finite-difference scheme. The spectral wave model SWAN (Booij et al., 1999; Ris et al., 1999) is run in a stationary mode to simulate the wave propagation and deformation from the open sea to the shoreline. Wave measurements available at intervals of $30 \mathrm{~min}$ are applied as offshore boundary conditions. This coincides with the interval of the sequential two-way coupling between SWAN and the hydrodynamic module (Delft3D-FLOW) that allows the exchange of rele- vant parameters on curvilinear model grids via a communication file. Wave parameters and the forcing terms associated with the wave radiation stresses computed by SWAN are read by the FLOW module. Once the assigned runtime of $30 \mathrm{~min}$ has been reached by FLOW, bottom elevation, water level and depth-integrated current fields are used as input to the computation in SWAN. The model will loop through these sequential module applications until the simulation is accomplished. The interaction of wave forces (radiation stresses), tidal currents and the changing bed- and water levels is thus realized by a fully coupled wave-current simulation.

Wave forces being computed in SWAN by radiation stress gradients are implemented as a shear stress in the flow module at the water surface layer. The ongoing debate about the vertical distribution of wave-induced radiation stresses that generally split up into a surface component, a bottom component and a body force and their implementation within 3D momentum equations (discussed in, for example, Ardhuin and Roland, 2013; Ardhuin et al., 2008; Bennis et al., 2011) reflects on and indicates that important wave-induced processes interacting with the flow circulation may still be inadequately implemented in Delft3D. These model limitations are, however, accepted in the present study assuming minor effects on the sedimentology and morphology at the tidal inlet.

Important wave effects are incorporated in the 3-D simulations as wave-induced mass flux adjusted for the vertically nonuniform Stokes drift, additional turbulence and vertical mixing processes and streaming as an additional 
wave-induced shear stress in the wave boundary layer (Walstra et al., 2000). The effects of wave asymmetry on the suspended sediment transports are included based on the nonlinear wave approximation modified by Van Rijn et al. (2004) after the method of Isobe and Horikawa (1982). Mean and oscillatory bed shear stresses interact nonlinearly. Through the use of the parameterization of Soulsby et al. (1993), the wave-current interaction model of Fredsøe (1984) is applied to account for the wave-induced enhancement of the bed shear stress that affects the stirring of sediments and increases the overall bed friction.

The sediment transport formulation applied here differentiates bed- and suspended load mechanisms (Van Rijn et al., 2004). Suspended load is treated above a reference height, and bed load below (Van Rijn, 1993). For simulations including waves, the magnitude and direction of the bed load transport are calculated using an approximation method developed by Van Rijn (2003). The method computes the bed load transport accounting for the flow velocity in the bottom computational layer and the near-bed peak orbital velocity in the direction of wave propagation. Suspended sediment is entrained in the water column by imposing a reference concentration (Van Rijn, 2000) at the reference height. An advection-diffusion equation (Van Rijn et al., 2004) is solved for the current-related suspended transport. The settling velocity of sand is computed following the method of Van Rijn (1993), where different suspended grain-size diameters are accounted for by empirical formulations. The vertical sediment mixing coefficient follows directly from the vertical fluid mixing coefficient calculated by the $k-\epsilon$ turbulence closure model (Rodi, 1984).

The model is used to identify sediment transport patterns between consecutive morphological states and to differentiate between instantaneous and residual suspended load and bed load directions and quantities. For details on the equations and processes implemented in the modeling system Delft3D, the reader is referred to Lesser et al. (2004), Van Rijn et al. (2004) or the manual of Delft3D (Deltares, 2011).

\subsection{Morphological acceleration factor}

A morphological scale factor is applied to account for the acceleration of bed level changes during updates at each hydrodynamic time step (Roelvink, 2006). Through the use of this method, which aims to economize computational runtime, hydrodynamic timescales are adapted to much longer timescales of morphological evolution. Within this study, a morphological acceleration factor (MORFAC) of 20 is applied during a simulation of 17 tidal cycles between neap and spring tide (7 to 15 June 2007) in order to account for morphological changes that occur during approximately 5 months of fair-weather conditions. For the 5-day storm simulation (6 to 10 November 2007), no morphological acceleration is applied (MORFAC $=1)$.

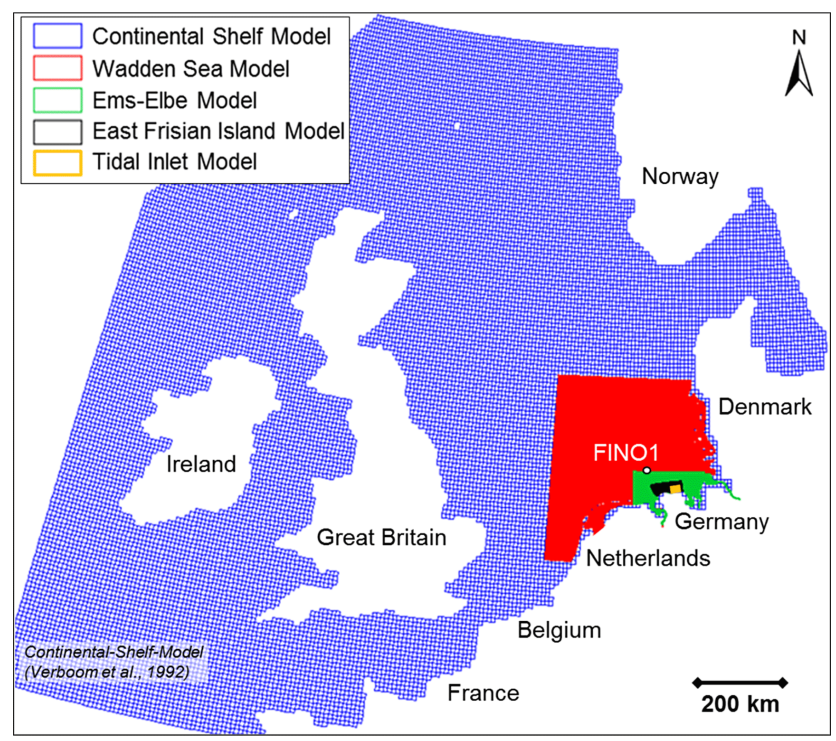

Figure 2. Cascade of five nested model grids and the position of wave measurements at FINO1 being applied as offshore boundary condition; wind- and atmospheric pressure fields computed by the German Weather Service cover all model grids.

\subsection{Model nesting and boundary conditions}

A hierarchical cascade of five model grids from the European continental shelf to the East Frisian barrier islands with decreasing spatial dimensions and increasing grid resolutions has been set up to derive water levels and wave climate at the study area (Fig. 2). Storm surge simulations in particular require large model domains as coastal surge is generated by wind drag effects and atmospherical pressure gradients acting over long distances on the open sea. The largest model with grid cell resolutions of $8000 \mathrm{~m}$ covers the continental shelf in the North Atlantic Ocean to the North Sea. Eight harmonic tidal constituents are applied to generate the astronomic tide at the sea boundaries of the continental shelf model (Verboom et al., 1992). It embeds the Wadden Sea model with average grid sizes of $1200 \mathrm{~m}$ covering the entire North Sea from the Dutch coast in the south to Denmark in the north. The Wadden Sea model, in turn, generates water level time series at the seaward boundary of the smaller EmsElbe model with grid resolutions of approx. $200 \mathrm{~m}$. The latter is additionally forced at the seaward boundary by wave data observed at the research platform FINO1 located $45 \mathrm{~km}$ offshore in water depths of $30 \mathrm{~m}$. The next smaller model covers the East Frisian barrier islands from Juist to Wangerooge with model grid resolutions of 60-120 m and supplies waveand water level boundary conditions to the most detailed tidal inlet model covering only Langeoog and Spiekeroog. At the end of the model cascade, this three-dimensional model with 10 sigma layers over the vertical is dedicated to simulate the sediment dynamics at the tidal inlet Otzumer Balje and adjacent beaches (Fig. 1). It consists of 140000 active grid 
cells with average grid resolutions of $60 \mathrm{~m}$ and up to $20 \mathrm{~m}$ in the breaker zones, assumed to be sufficiently resolved for proper generation of wave-induced alongshore currents during storm conditions. During fair-weather conditions, wavelengths are significantly shorter and the selected cross-shore grid resolution may not be ideally represented at the upper part of the beach, yet certain limitations are accepted in favor of reduced computational times.

\subsection{Model bathymetry}

Model bathymetries, i.e., depth schematizations for each particular model (Sect. 3.2), have been assembled by interpolating measured data of sea bottom elevations onto curvilinear model grids. Near coastal sub- and intertidal areas are covered by data of the years 2006, 2005 and 2001 based on conventional sounding methods (Federal Maritime and Hydrographic Agency, BSH). Elevations of inter- and supratidal barrier island beaches are partly covered by beach profiles of the year 2007 or high-resolution airborne lidar scans that are spatially limited and available for the years 2008, 2007 and 2005 (data with permission of the Coastal Research Station of Lower Saxony Water Management, Coastal Defense and Nature Conservation Agency - FSK-NLWKN).

\subsection{Meteorological forcing}

Storms in the central part of the North Sea are associated with low-pressure systems. During the investigated extreme storm event, Tilo, between 5 and 10 November 2007, with peak surge levels on 9 November 2007, maximum wind velocities of $33 \mathrm{~m} \mathrm{~s}^{-1}$ and mean wind directions of north-northwest were recorded offshore (Outzen et al., 2008). Wind stress and horizontal atmospheric pressure gradients acted over a long fetch from the Arctic Sea across the entire North Sea inducing extreme surge setup superimposed by high astronomical tide. The storm surge simulations are forced by meteorological model data of the German Weather Service (DWD). Wind and atmospheric pressure fields are available at $1 \mathrm{~h}$ intervals and spatial resolutions of 7 and $2.8 \mathrm{~km}$ for the models COSMO-EU and COSMO-DE, respectively.

The simulation representing fair-weather hydrodynamic conditions is forced by time series of wind data measured at the research platform FINO1 (provided by BMU, PTJ). Realtime data between 7 and 15 June 2007 are imposed to the wave and hydrodynamic simulations to account for a meteorological forcing with nonstationary wind velocities and directions. The mentioned period was selected based on visual comparison of generated wind roses due to the selected data set and a 2-year data set. Thus the selected data do not fulfill long-term statistical correctness, but the overall distribution of wind directions and intensity are similar to the long-term trend. Wind directions of the selected data series are from the westerly sector with a short intermittent period of easterly winds. The selected data are assumed to be sufficiently representative to account for typical low-energy wind- and wave conditions.

\subsection{Multiple-grain-size model}

\subsubsection{Bed layer model for multiple sediment fractions}

A dynamic bed layer model is applied that permits the redistribution of multiple sand fractions in relation to imposed bed shear stresses. It thus enables the computation of spatial distributions of surface sediment grain-size fractions and to evaluate arithmetic mean grain sizes in response to different hydrodynamic conditions. Each sand fraction depletes or increases in the bed cell according to erosion or deposition processes in the sediment transport formulation. A coefficient according to each mass percent is applied in the transport equation to account for the availability of the mobilized sand fraction at a given bed cell. Thus, sediment transport occurs if the critical shear stress is exceeded for a certain grainsize fraction, whereas its load is additionally controlled by the relative availability of each sand fraction. The uppermost layer of the bed layer model, the so-called active layer, has a constant thickness and records the grain-size composition of the underlayers beneath. The underlayers account for the bed level change, while their thicknesses increase or decrease depending on the prevailing erosion or deposition of a certain grain-size fraction. In the present study, the selected active layer thickness is $0.25 \mathrm{~m}$. At the start of the simulation, the total thickness of the underlayers is $10 \mathrm{~m}$ in order to guarantee enough sediment supply in case of locally strong erosion. Simulations presented in this study consider continuous bed level updating. This is clarified against the background that Delft3D allows simulations without bed level updating but redistribution of sediment fractions only. For details on the setup and functioning of the bed layer model, the reader is referred to Van der Wegen et al. (2011a).

In the present study, because of computational expenses, model simulations were restricted to a limited number of noncohesive sand fractions (five), with grain sizes of 150 , $200,250,350$ and $450 \mu \mathrm{m}$. As the focus is on the sediment dynamics at the tidal inlet, a characteristic gradation of rather coarse sediment fractions between 150 and $450 \mu \mathrm{m}$ was selected. Areas exposed to a low-energy wave impact such as the back-barrier tidal flats or the lower shoreface where significantly finer grain sizes occur in nature are, according to the grain-size configuration selected here, not subject to significant morphological changes and thus grain-size sorting processes. Here, the initial mean surface sediment grain size does not change significantly during the simulations. This limitation is tolerated because back-barrier sediment dynamics and exchange processes between the back-barrier basin and the foreshore are not the focus of this study. Back-barrier tidal flats contain high amounts of fine sand and cohesive sediments and would require a different model setup and grain-size configuration. 

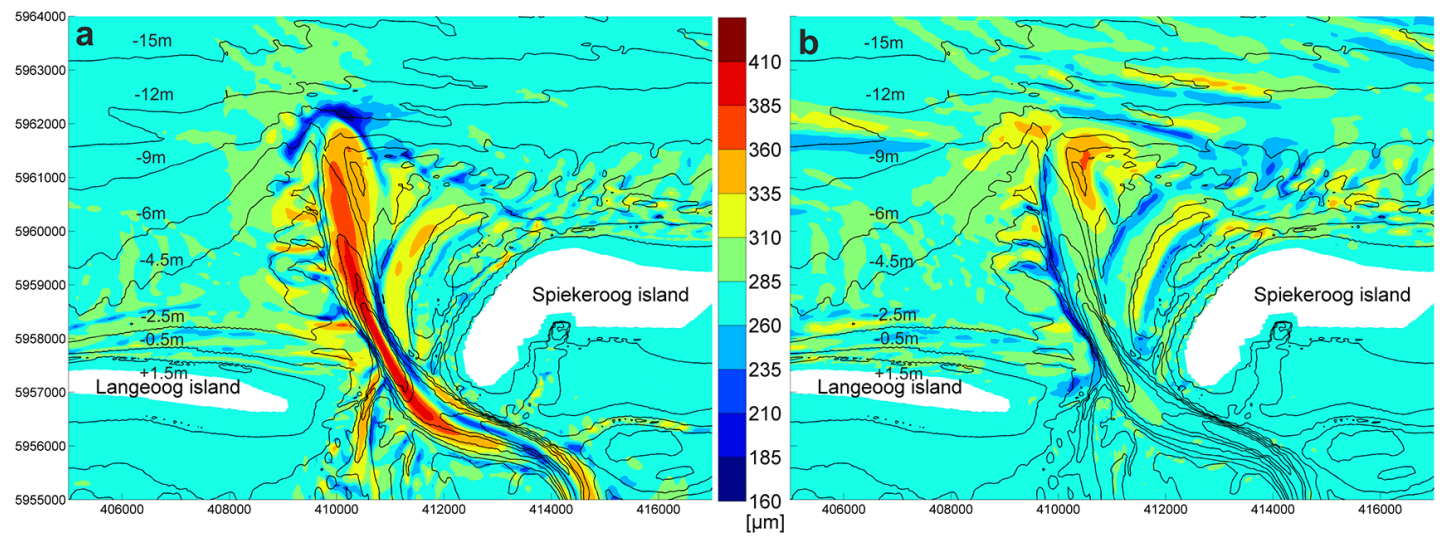

Figure 3. Distribution of arithmetic mean surface sediment grain sizes as a response to fair-weather (a) and storm (b) conditions; synthetic simulations were initiated with five uniformly distributed sand fractions between 150 and $450 \mu \mathrm{m}$.

\subsubsection{Initial sediment grain-size distribution}

Observations of surface sediments are restricted to the tidal inlet Otzumer Balje; samples of the ebb-tidal delta lobe are not available. The spatial inconsistency of measurements precludes the use of grain-size observations as initial conditions of simulations. The model is thus applied to allow for the redistribution of multiple sand fractions with the objective of generating a schematization of the observed surface sediments that can then be used to initiate more realistic simulations. According to this, two different model initializations are considered: on the one hand, the synthetic case of an initialization with uniform grain-size distribution; on the other hand, the more realistic "analysis simulations" taking into account a sediment distribution of nonuniform grain sizes that was generated by preceding model runs.

Synthetic simulations are initiated with uniform sediment type distribution. Five sediment fractions (150, 200, 250, 350 and $450 \mu \mathrm{m})$ are available at 20 mass percent each and thus represent an initial mean grain size of $280 \mu \mathrm{m}$. First, two synthetic simulations are run and forced by approximately 5 months of fair-weather conditions and 5 days of storm conditions to exemplify the sedimentological response to tideand wave-dominant hydrodynamic conditions for simplified sedimentological settings. For fair-weather conditions, elevated shear stresses due to tide-induced currents in the inlet throat and marginal channels cause mean sediment grain sizes at the channel bottoms to increase, while fine sands are entrained, transported in the ebb direction and deposited at the ebb-tidal delta lobe (Fig. 3a). During storm conditions, however, sediment coarsening occurs due to wave-induced stirring and increased shear stresses at the ebb-tidal delta and adjacent shoals, whereas sediments at the tidal channels reveal only minor changes in mean grain size (Fig. 3b). Fine sediments being entrained by northwesterly waves on the elevated shoals are transported in the onshore direction and accumulate as elongated deposits along tidal channel margins. These simulations reveal synthetic sediment distribu-

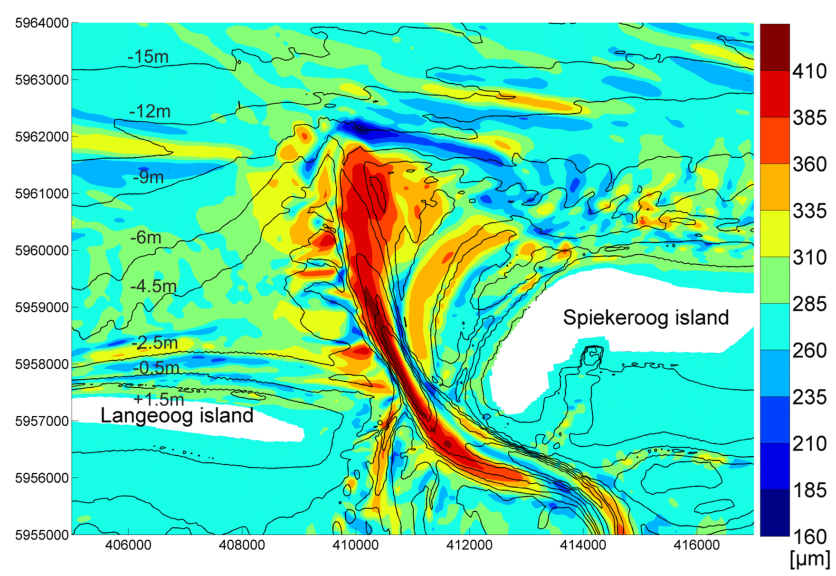

Figure 4. Arithmetic mean surface sediment grain size due to the distribution of five sand fractions between 150 and $450 \mu \mathrm{m}$ generated by a series of three simulations with alternating hydrodynamic forcing due to 5 months of fair-weather conditions, an extreme storm event and again 5 months of fair-weather conditions.

tions since sediments in nature are nonuniformly distributed and sediment grain-size availability may be a crucial factor in the development of sediment fluxes; however, they allow for highlighting of the idealized response of surface sediments to distinct hydrodynamic forcing conditions.

As a second step, a more realistic sediment distribution is generated that is in response to a combination of fair-weather and storm conditions: a simulation of 5 months being forced by fair-weather boundary conditions is followed by a storm simulation of 5 days and another period of 5 months of fairweather conditions. Sediment mass fractions at the end of each model run are turned over to the subsequent simulation. At the end of the sequence of simulations, the predicted sediment distribution schematizes the sedimentological response to a mixed-energy tidal inlet regime (Fig. 4). This sediment distribution is used for model validation purposes based on a 
qualitative comparison of predicted and observed grain-size distributions (Sect. 4.3). Furthermore, it is applied as an initial condition for simulations that aim to analyze morphodynamics and sedimentology in response to fair-weather and storm conditions (Sects. 5 and 6), because it allows for a more realistic schematization of surface sediments with consistency all over the model domain and one avoids having to rely on spatially limited sediment grain-size measurements.

\section{Model validation}

The model system Delft3D has been widely tested in morphodynamic modeling studies for various environments (e.g., Dissanayake et al., 2009; Lesser et al., 2004; Van der Wegen and Roelvink, 2012), yet it has been verified in comparably few morphological studies on nonidealized tidal inlets that take into account a real-world bathymetry (e.g., Elias and Hansen, 2013; Elias and van der Spek, 2006; Elias et al., 2012). The validation of simulated morphodynamics by field observations is generally difficult as in situ data are scarce and only available for very limited areas, if at all. This particularly applies to bathymetrical data measured just before and after a storm surge event. Data on storm-induced bed evolution are necessary for model calibration and verification purposes. Available observations and published data of the studied tidal inlet and adjacent barrier islands beaches are summarized and compared to modeled hydrodynamics, sediment dynamics and surface sediment grain-size distributions in order to determine the validity of the modeling approach below. Modeled data are from the two most detailed model domains of the cascade of nested model grids (Fig. 2).

\subsection{Hydrodynamics}

Time series of simulated water levels are compared to observations at available tidal gauges within the study area (data provided by the Federal Agency of Water and Navigation, WSV). Figure 5 shows modeled versus observed water level time series for the storm surge event at Spiekeroog tidal gauge. High water levels are generally well reproduced by the model, whereas low water levels show discrepancies. The phase lag between modeled and measured water level time series is in the range of $10-20 \mathrm{~min}$. The root-meansquare errors (RMSE) for the water level amplitudes for the fair-weather and storm simulations are 12 and $19 \mathrm{~cm}$ at Spiekeroog and 14 and $22 \mathrm{~cm}$ at Langeoog.

Wave data measured during the storm event at the surf zone of the island of Norderney are available from a project report of the FSK-NLWKN (Kaiser et al., 2008). The island of Norderney is located $25 \mathrm{~km}$ to the west of the studied tidal inlet. The downward-looking ultrasound device mounted on a pole produced corrupted data once the distance between the water surface and the sensor was too small, due to unexpectedly high surge levels. Approximately $1 \mathrm{~h}$ before, on 9 November 2007 at 07:00 UTC, a time-averaged significant

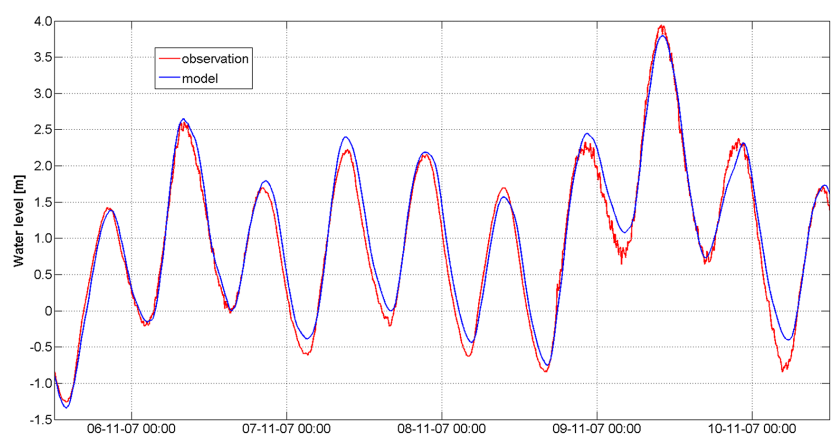

Figure 5. Comparison of modeled and observed water level time series at the water level gauge Spiekeroog for the storm event "Tilo" with peak surge levels on 9 November 2007.

wave height of $3.5 \mathrm{~m}$ is qualitatively compared to predictions of the storm simulation of the next larger model grid ("East Frisian Island Model", Fig. 2). The measured wave height is underestimated by $17 \%$ in the simulation and thus confirms fair reliability of the predicted wave energy in the surf zone.

Time series of water levels and wave parameters were measured during the storm event at an observational pole located in the inner part of the Accumer Ee inlet separating the islands of Baltrum and Langeoog. The pole was operated between the years 2000 and 2007 by Helmholtz-Zentrum Geesthacht. Its configuration and functioning is described in Onken et al. (2007). The pole's location was not directly at the studied tidal inlet, but was still within the most detailed model domain (Fig. 1). The observation point is located at a hydrodynamic complex and morphologically dynamic location at the junction of the main tidal channel and a larger tributary. Here, bathymetrical information is only available for spring 2005 and has been incorporated in the model bathymetry, two years ahead of the chosen validation period of November 2007. Local differences between the real and the model bathymetry may influence the local wave regime, making a quantitative model validation based on the existing observations ambiguous. Observed wave parameters were calculated from water level elevations recorded at a frequency of $2 \mathrm{~Hz}$ taken from a floater guided along a rod with a magnetic readout. Spikes and stuck values were cleaned from the data. The effect of this data cleaning is shown in Lane et al. (2000) and the usage of floater-derived wave parameters for model validation in the North Frisian Sylt-Rømø Bight demonstrated in Schneggenburger et al. (2000).

Phases and amplitudes of the observed water levels and wave parameters are fairly well reproduced by the model in view of the complexity of the wave-current interactions at the measuring site (Fig. 6). For significant wave height $(\mathrm{Hs})$, model data exhibit a bias of $0.24 \mathrm{~m}$. Statistical analysis of model predictions with respect to the observations allows for evaluation of the RMSE of $0.19 \mathrm{~m}$ for the water level, $0.26 \mathrm{~m}$ for $\mathrm{Hs}, 0.69 \mathrm{~s}$ for the peak wave period (Tp) and $0.34 \mathrm{~s}$ for the mean wave period $(\mathrm{Tm})$. Discrepancies 

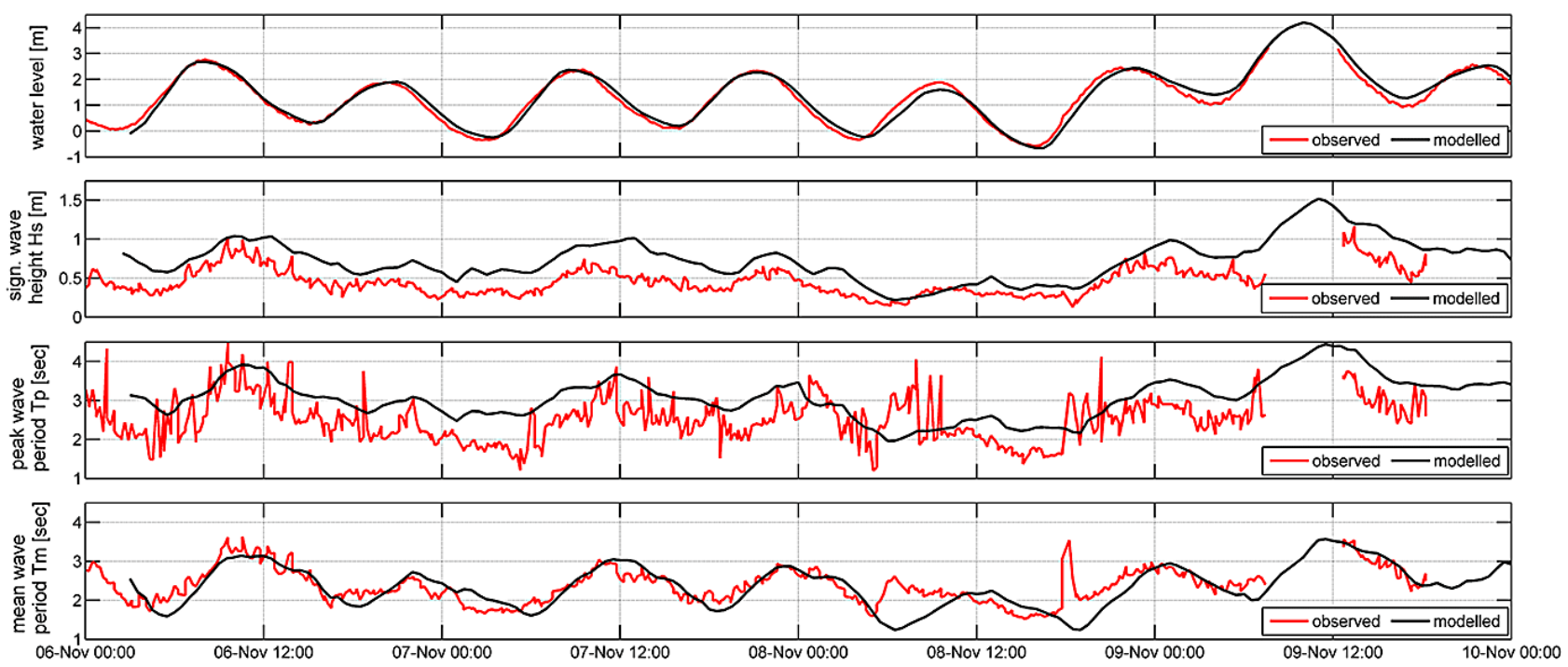

Figure 6. Observed and modeled water levels, significant wave heights (Hs), peak wave periods (Tp) and mean wave periods (Tm) at the back barrier of Langeoog during Tilo in November 2007 (observations provided by Helmholtz-Zentrum Geesthacht).

tend to be slightly larger during ebb and low water compared to flood. One explanation is that the measuring pole was exposed to the focused ebb currents in the tributary tidal channel that were opposite to wave propagation. The overestimated wave height during ebb may be a consequence of insufficient wave dissipation due to whitecapping incorporated by the saturation-based whitecapping formulation of Van der Westhuysen (2007). The enhanced dissipation of waves on negative current gradients after a recently published formulation (Van der Westhuysen, 2012) was successfully applied in Dodet et al. (2013). In the present study, however, uncertainty as to the bathymetry at the measuring site does not allow for the calibration of the model by the application of different whitecapping formulations.

It should be noted that no model calibration was performed by spatially varying bed roughness adaptation. Instead, the bed roughness was set to a uniform, constant value over the model domain (Manning parameter 0.024). Particularly against this background, this validation attests adequate model skill for the purpose of this study.

\subsection{Sediment dynamics and morphology}

Time series measurements of suspended matter (SPM) concentrations observed at the tidal inlet Otzumer Balje during the storm surge peak tide on 9 November 2007 show hourly mean (maximum) values on the order of $35(65) \mathrm{mg} \mathrm{L}^{-1}$ and 55 (95) $\mathrm{mg} \mathrm{L}^{-1}$ for maximum flood- and ebb-tide currents, respectively, at $0.5 \mathrm{~m}$ below mean low water level (Badewien et al., 2009). The three finest sediment fractions incorporated in the model simulation $(150,200$ and $250 \mu \mathrm{m})$ reveal hourly mean (maximum) SPM concentrations of $45(70) \mathrm{mg} \mathrm{L}^{-1}$ during maximum flood-tide currents at $2 \mathrm{~m}$ below German datum at the location of the measuring pole. During flood tide, SPM concentrations at the inlet are due to nearshore wave-induced sand resuspensions. The model reproduces suspended sediment dynamics fairly well for these conditions: hourly mean and maximum concentrations are overestimated by approximately 29 and $8 \%$, respectively. During ebb tide, however, predicted maximum SPM concentrations of $2 \mathrm{mg} \mathrm{L}^{-1}$ are strongly underestimated with respect to measurements $\left(95 \mathrm{mg} \mathrm{L}^{-1}\right)$. This can possibly be explained by the fact that fine sand $(<150 \mu \mathrm{m})$ and cohesive sediments that are typically flushed out of the back-barrier tidal flats during increased storm surge ebb-flows (Bartholomä et al., 2009; Cuneo and Flemming, 2000) are simply not incorporated in this model setup. However, discrepancies here are not relevant for this study, because the model is not applied to predict residual sediment rates between the foreshore and back-barrier basin.

Observations of morphological changes as a response to the storm event of November 2007 are available for two cross-shore profiles at the foreshore of Langeoog, both extending from the coastal dune up to a distance of $3900 \mathrm{~m}$ from the beach into water depths of $14 \mathrm{~m}$ below German datum. Data of profiles 37 and 38 measured at Langeoog on 15 October and on 12 and 22 November 2007 by the Coastal Research Station were processed with permission from NLWKN (Kaiser et al., 2008). A direct comparison of observed and modeled morphological changes is not possible because bathymetrical data of spring 2006 being used to set up the model bathymetry do not coincide with the cross-shore profiles that were measured in October and November 2007. Morphological changes along these profiles are thus qualitatively compared to predicted patterns of erosion and sedimentation of the storm simulation (Appendix A). 

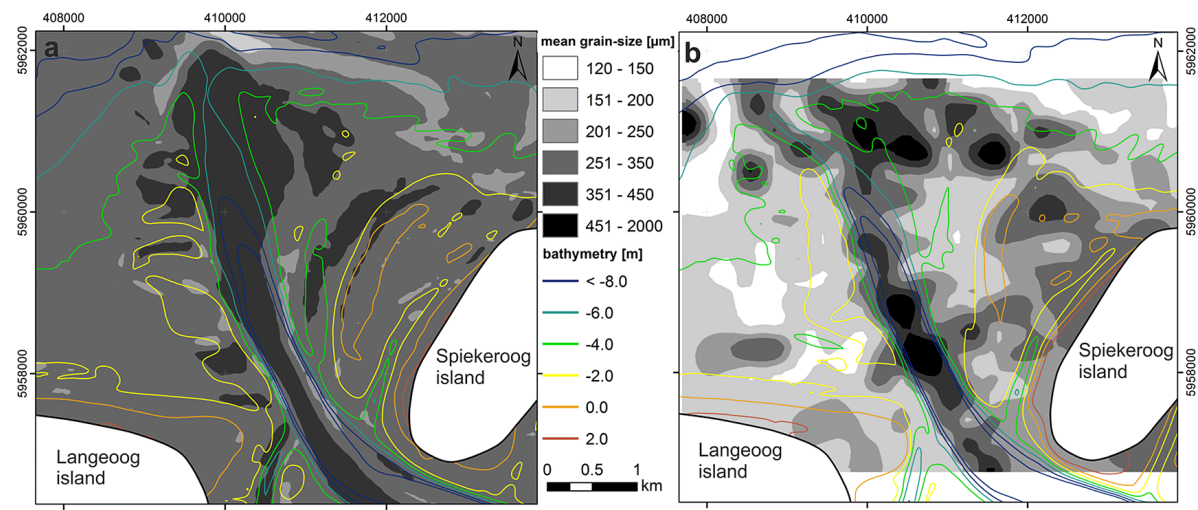

Figure 7. Modeled (a) and measured (b) arithmetic mean surface sediment grain-size distributions at Otzumer Balje inlet between Langeoog and Spiekeroog; depth isolines based on bathymetrical data measured in 2006/2007 (a) and 2004/2005 (b).

Morphological changes evaluated from observations are on the order of $0.5 \mathrm{~m}$ to $1.0 \mathrm{~m}$ at the surf zone within the first $500 \mathrm{~m}$ of the profiles (Figs. A1 and A2). This order of magnitude is reproduced by the model; in particular, the erosion of the upper beach and the filling of the trough of the first berm are generally captured by the model (Fig. A3). Between 500 and $2000 \mathrm{~m}$ from the beach, the downdrift migration of two shore-oblique sand bars through the transversal profiles generates alternations in erosion and deposition of approximately $0.5 \mathrm{~m}$, which reveals good agreement with model predictions. At $2000-3500 \mathrm{~m}$ from the shoreline, mostly deposition on the order of 0.1 to $0.3 \mathrm{~m}$ is observed. The landward trough of the shoreface-connected ridge at the end of the profiles accumulates sand, whereas the adjacent slopes tend to suffer from erosion. Predicted sand depositions of 0.05 to $0.1 \mathrm{~m}$ in between depth isolines -6 and $-9 \mathrm{~m}$ are underestimated by the model.

This qualitative analysis shows fair similarities between model predictions and observations in terms of magnitude and alteration from net sedimentation to net erosion at the described morphological compartments.

\subsection{Sedimentology}

Mapping of surface sedimentology of the whole domain of interest is not available. However, Son et al. (2010) compiled surface sediment grain-size distributions in the Otzumer Balje tidal inlet from a grid of Shipek sediment grab samples at distances of approximately $280 \mathrm{~m}$ for the year 2005 . Their data are reinterpolated here to allow for comparison with modeled data. Modeled mean surface sediment grain sizes are due to redistributions of five sand fractions between 150 and $450 \mu \mathrm{m}$; and are generated by a series of three model runs with alternating hydrodynamic forcings due to fairweather conditions, storm conditions and then fair-weather conditions once more (Sect. 3.5, Figs. 4 and 7a).

The initial bathymetry of the detailed tidal inlet model is based on bathymetrical data of the years 2006 and 2007 and thus different from the inlet morphology of the sediment sampling campaign of 2005 , here indicated by isolines based on available bathymetrical data of the years 2004 and 2005 (Fig. 7). The different morphological background explains the westerly bend of the channel through the ebb-tidal delta for the sampling state compared to a more straightened orientation in the model bathymetry.

Modeled and measured arithmetic mean surface sediment grain-size distributions show distinct similarities (Fig. 7). Surface sediments are coarsest at the inlet channel, the ebbtidal delta and the eastern ebb-tidal delta shoal where swash bars migrate onshore. The central part of the ebb-tidal delta with medium to coarse sands is divided by a characteristic south-north-oriented pattern of finer mean grain sizes shown by both modeled and measured distributions. At the foreshore, modeled mean grain sizes are generally coarser with respect to measurements. This is explained by the selection of the initial mean surface sediment grain size of $280 \mu \mathrm{m}$ composed of five uniformly distributed fractions that tend to be too coarse for specific areas, e.g., the foreshore or the back-barrier tidal flats, particularly as the performance of the model to predict surface sediment grain sizes decreases as morphological changes are small and thus sorting of sand fractions cannot take place.

At the western ebb-delta shoals, on the other hand, distinct grain-size patterns of medium sand that are predicted by the model cannot be validated by field data as the distance between sample positions (approx. $280 \mathrm{~m}$ ) is too large for these spatial patterns in surface sediment grain sizes to properly be resolved.

\section{Results}

We compare the effect of an extreme storm surge event in the North Sea to a medium-term period (approx. 5 months) of representative fair-weather conditions on morphodynamics and sedimentology at the tidal inlet Otzumer Balje between the barrier islands Langeoog and Spiekeroog based on two model simulations. 


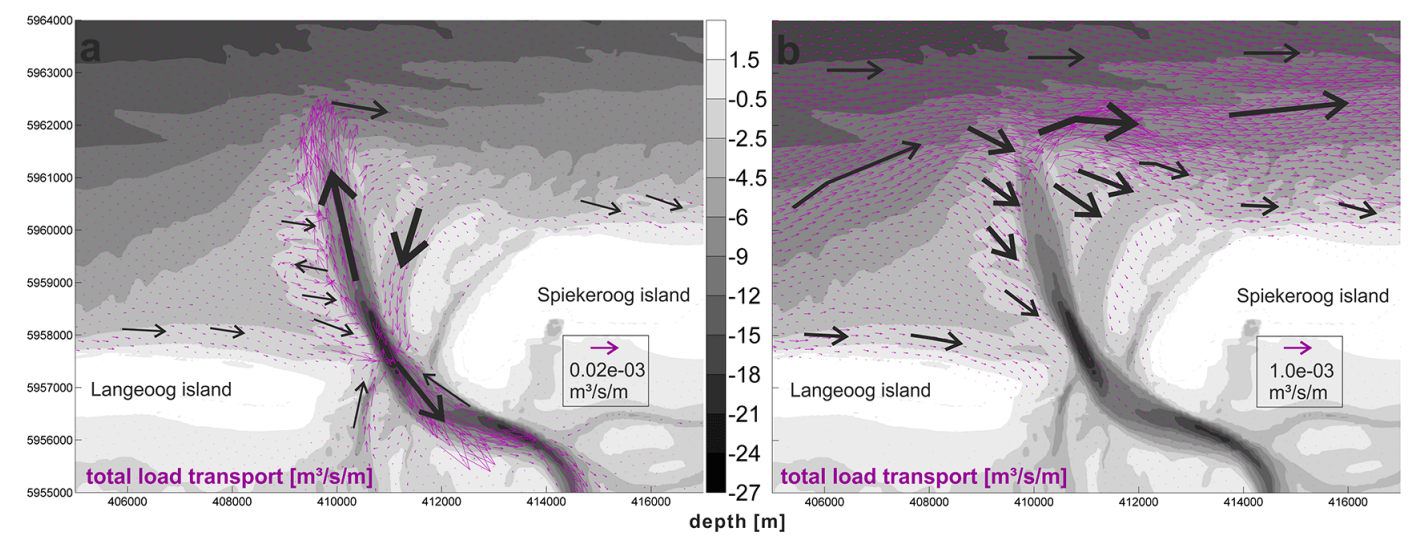

Figure 8. Residual total load transport for fair-weather conditions (a) and storm conditions (b); schematic main residual pathways indicated by black arrows.

Both simulations reveal sediment pathways for five distinct sediment fractions of $150,200,250,350$ and $450 \mu \mathrm{m}$. Residual total load (suspended and bed load) sediment transport of small sand fractions, i.e., 150 and $200 \mu \mathrm{m}$, shows pathways comparable to the residual suspended load sediment transport of all five fractions. On the other hand, residual total load transports of coarser sand fractions, i.e., 350 and $450 \mu \mathrm{m}$, resemble the pathways of the overall residual sediment transport due to bed load quantities. This is not unexpected and means that pathways of individual grainsize fractions do not give significant additional information compared to a presentation that only differentiates between pathways of bed load and suspended load transport. Figures of residual sediment transport pathways integrated over all five sand fractions are thus presented hereafter as total load, bed load or suspended load quantities.

It may be noted here that the morphological acceleration factor, i.e., MORFAC $=20$ (Sect. 3.2), being applied during fair-weather simulations only accounts for an accelerated development of the morphology and the sediment grain-size distribution; however, it does not apply in the computation of sediment transport loads. The residual sediment transport load $\left[\mathrm{m}^{3} \mathrm{~s}^{-1} \mathrm{~m}^{-1}\right]$ is thus the time-averaged transport load over a runtime of 17 tidal cycles during fair-weather conditions and of 9 tidal cycles during the storm event.

\subsection{Tide-dominated fair-weather conditions}

Residual total sediment transport fluxes during fair-weather conditions are largest in the vicinity of the tidal inlet, particularly in the inlet throat and the eastern marginal flood channel (Fig. 8a). The residual total load sediment fluxes are differentiated into residual bed load transports (Fig. 9a) and residual suspended load transports (Fig. 9b). Residual suspended load quantities are approximately 4 times larger than the residual bed load quantities, but their residual directions are similar. North of the deepest location in the inlet throat, residual transport is ebb-dominant and directed towards the ebb-tidal delta, whereas southwards it follows the inlet channel towards the flood delta and the back-barrier basin.

At the easterly end of Langeoog, alongshore net sediment drift supplies bed- and suspended load towards the inlet throat of the tidal inlet. At the western ebb-tidal delta shoal, a residual sediment import to the inlet throat takes place over the shallow shoals, whereas predominantly suspended sediment load is exported via ebb channels located in between these shoals.

At the northern part of the eastern ebb-tidal delta shoal, minor residual bed- and suspended load quantities are transported in a sharp bend from the center of the ebb-tidal delta to the eastern ebb-tidal delta shoal in a south-southeasterly direction. With increasing water depths landwards of the shoal, the sand is directed into a deeper, transverse tidal channel. Through this flood-dominant, marginal tidal channel significant residual suspended and bed load quantities are transported in a south-southwesterly direction back to the tidal inlet throat.

At the inlet widening towards the back-barrier tidal basin, the inlet throat is flood-dominant. Residual fluxes of predominantly suspended sediment point along the main inlet channel towards the flood-tidal delta and adjacent tidal flats. At the northern margin of the main channel and alongside the western head of Spiekeroog, minor residual bed- and suspended load fluxes are opposite and thus ebb-directed via a bordering transport pathway. Between the easterly end of Langeoog and the flood delta, a marginal tidal channel is also ebb-dominated and leads residual suspended and bed load fluxes out of the basin.

The mid-term fair-weather simulation reveals morphological and sedimentological changes at the tidal inlet and adjacent channels, at shore-parallel bars in the surf zone and shore-oblique sand bars (Figs. 11a and 12a). Sediment dynamics at the foreshore are insignificant and net morphological changes are below $0.05 \mathrm{~m}$ (Fig. 11a). Sediments being eroded in the inlet throat and tributary channels 


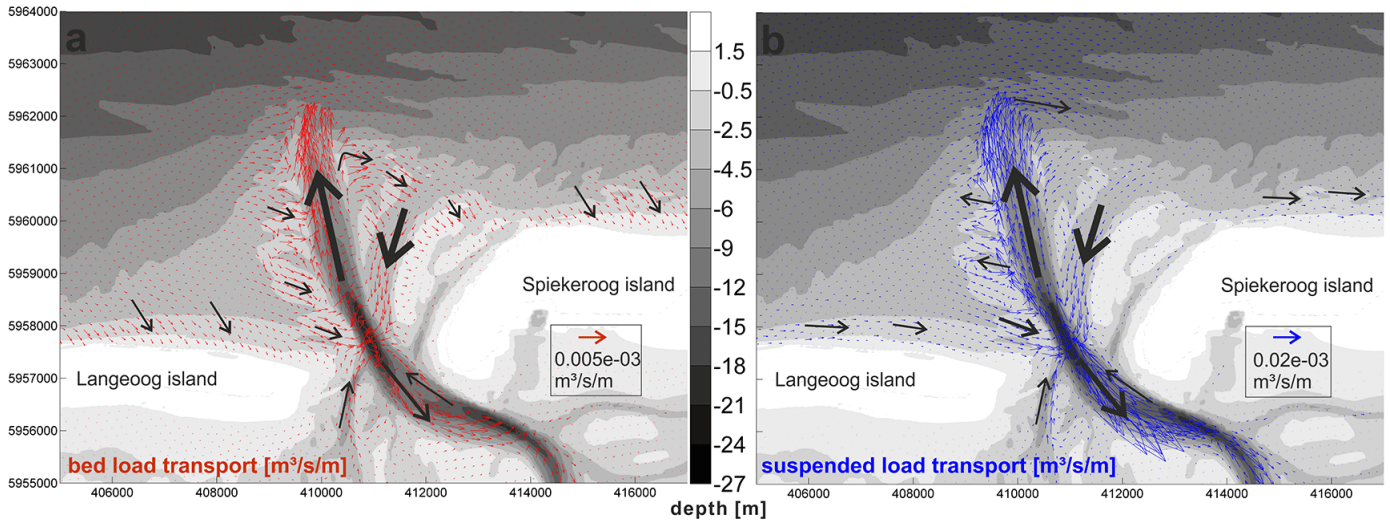

Figure 9. Residual bed load (a) and residual suspended load (b) transport for fair-weather conditions; schematic main residual pathways indicated by black arrows. Relative vector scaling indicates suspended load to be approx. 4 times larger than bed load transport.

are transported and deposited at the ebb-tidal delta and adjacent shoals. The most northern part of the ebb-tidal delta increases and protrudes offshore with net depositions exceeding $1.0 \mathrm{~m}$ at the ebb-delta lobe during the simulated period of 5 months.

The sediment distribution shows a relative coarsening of the mean surface sediment grain size on the order of 30 $50 \mu \mathrm{m}$ at the western ebb-tidal delta shoals and at the tidal channels, whereas the ebb-tidal delta lobe is fed by the entrained finer sand fractions and decreases the mean grain size by approx. 30-40 $\mu \mathrm{m}$ (Fig. 12a). Sedimentological changes are in relation to the initial, nonuniform sediment distribution (Fig. 4); thus the redistribution of surface sediments is small because the sedimentological response to fair-weather hydrodynamic conditions is largely included in the initial condition already. The absolute mean sediment grain-size distribution due to synthetic simulations (Fig. 3a), however, shows that the depositional area at the ebb-tidal delta experiences a grading of sediment grain sizes. The finest sand is deposited at the outermost ebb-tidal delta lobe where ebb-directed current velocities decrease due to increasing water depths.

Shore-oblique sand bars migrate eastwards in the same direction as the overall littoral sediment drift (Fig. 11a). Similar to fluvial low-energy bed forms, erosion takes place on the stoss side and sedimentation on the lee side. Once again, synthetic simulations reveal a gradient in mean surface sediment grain sizes with medium (fine to medium) sands at the upper stoss side and the crest (lee side and trough) (Fig. 3a); this indicates that tide-dominated alongshore current velocities during fair-weather conditions are strong enough to develop typical sediment gradients over morphological features.

\subsection{Wave-dominated high-energy storm conditions}

During the storm event, residual eastward-directed total sediment fluxes are predicted to be largest at the barrier island foreshore, particularly directly off the ebb-tidal delta, whereas residual sediment load is very small in the tidal inlet throat (Fig. 8b). Across the tidal inlet, the residual total sediment transport direction is flood-dominant, but only a marginal amount of sand tends to be imported to the backbarrier basin. The residual total load transport is differentiated into residual bed- and suspended load transport vectors (Fig. 10a and b). Disregarding the residual transport directions, the relative scaling of the vectors indicates that the net suspended load quantity is overall approximately one order of magnitude higher than the net bed load quantity. The residual bed load transport is south-southeastward-directed, particularly at the eastern ebb-tidal delta shoal where it drives the migration of swash bars. The residual bed load transport direction agrees with the mean direction of wave propagation. Residual suspended sediment transport load is largest close to the ebb-tidal delta and in the extended surf zone from the islands' beaches to the transition of upper to lower shoreface. Here, residual directions are downdrift-oriented due to wave-induced alongshore currents that advect the entrained sand to the east.

During the storm event, significant morphological and sedimentological changes occur over large areas of the barrier island foreshore and upper shoreface, but particularly in the northern part of the ebb-tidal delta (Figs. 11b and 12b). Highenergetic waves refract and break on the depth-limited ebbtidal delta shoals, stirring large quantities of sediment. In the vicinity of the ebb-tidal delta, morphological changes along distinct linear patterns are predicted to be $1 \mathrm{~m}$ or more during this storm event (Fig. 11b). Fine sand fractions of 150, 200 and $250 \mu \mathrm{m}$ are transported as suspended load by the combined flow of tide-, wind- and wave-induced currents downdrift to the east. Mostly medium-sized sands with sand fractions of 250, 350 and $450 \mu \mathrm{m}$ remain, and as a result they increase the mean surface sediment grain size by up to $100 \mu \mathrm{m}$ at the most seaward part of the ebb-tidal delta shoal (Fig. 12b). 


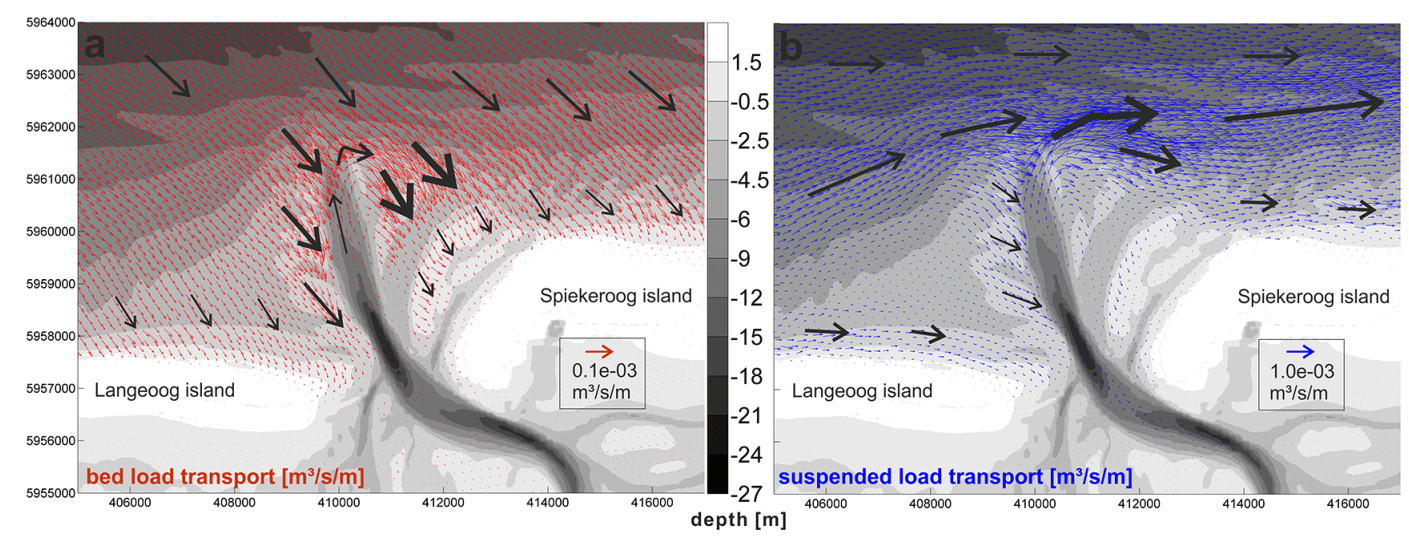

Figure 10. Residual bed load (a) and residual suspended load (b) transport for high-energy storm conditions; schematic main residual pathways indicated by black arrows. Relative vector scaling indicates suspended load to be approx. 10 times larger than bed load transport.

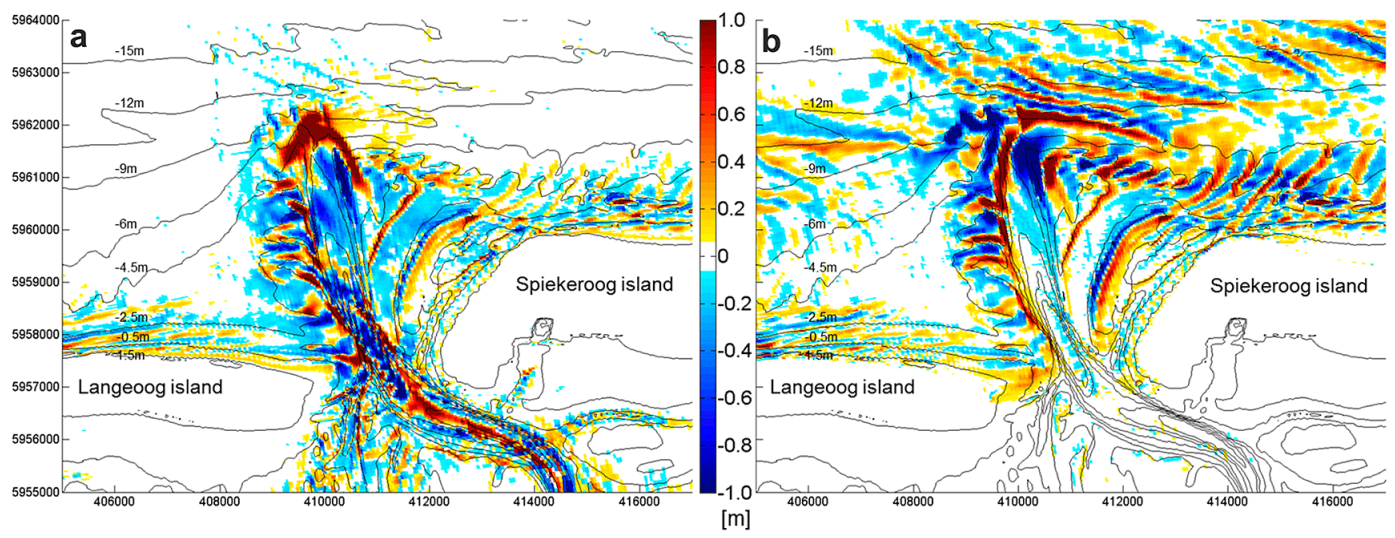

Figure 11. Morphological changes, i.e., sedimentation (red) and erosion (blue) as a response to fair-weather (a) and storm (b) conditions; analysis simulations were initiated with nonuniformly distributed sediment fractions (Fig. 4).

The morphology and sedimentology of the inlet throat and marginal flood channels are less affected, as the driving wave energy is dissipated at the shallow ebb-tidal delta shoals. In addition, bottom shear stress decreases as the tidal flow slows down through the relatively increased cross-sectional area of the inlet because of elevated surge levels.

Grain sizes increase insignificantly at the inlet gorge, whereas fine sands accumulate at the western margin of the inlet throat (Fig. 12b). Here, transport over the western ebb-tidal delta shoal directs finer sand south-southeastwards to the western margin of the inlet throat where settling starts, with increasing water depths and thus decreasing shear stresses causing a lateral shift of the inlet throat to the east (Fig. 11b).

At the eastern ebb-tidal delta shoal, alternating erosion and deposition patterns indicate a south-southeastward migration of large swash bars that are oriented almost parallel to the shore and thus deviate from shore-oblique sand bars (Fig. 11b). At the northeastern edge of the ebb-tidal delta shoal, shore-oblique sand bars connecting the eastern ebbtidal delta with the downdrift surf zone migrate eastwards during storm conditions. The sediment distribution due to the synthetic simulation being initiated with uniformly distributed sediment fractions predicts coarser grain sizes at the bed form crests with respect to the troughs of the shoreoblique sand bars (Fig. 3b). Analysis simulations of the storm event being initiated by a nonuniform sediment distribution (Fig. 4) reveal this gradient to be further enhanced (Fig. 12b).

At the lower shoreface, fine sand fractions are winnowed and eroded in the troughs between and at the landward slopes of shoreface-connected sand ridges being located in water depths of 15-20 m below German datum (Fig. 12b). Fine sand tends to accumulate on the crests and the seaward slopes of the shoreface-connected ridges. Thus the shorefaceconnected ridges experience a positive morphological feedback and a downdrift migration (Fig. 11b). 


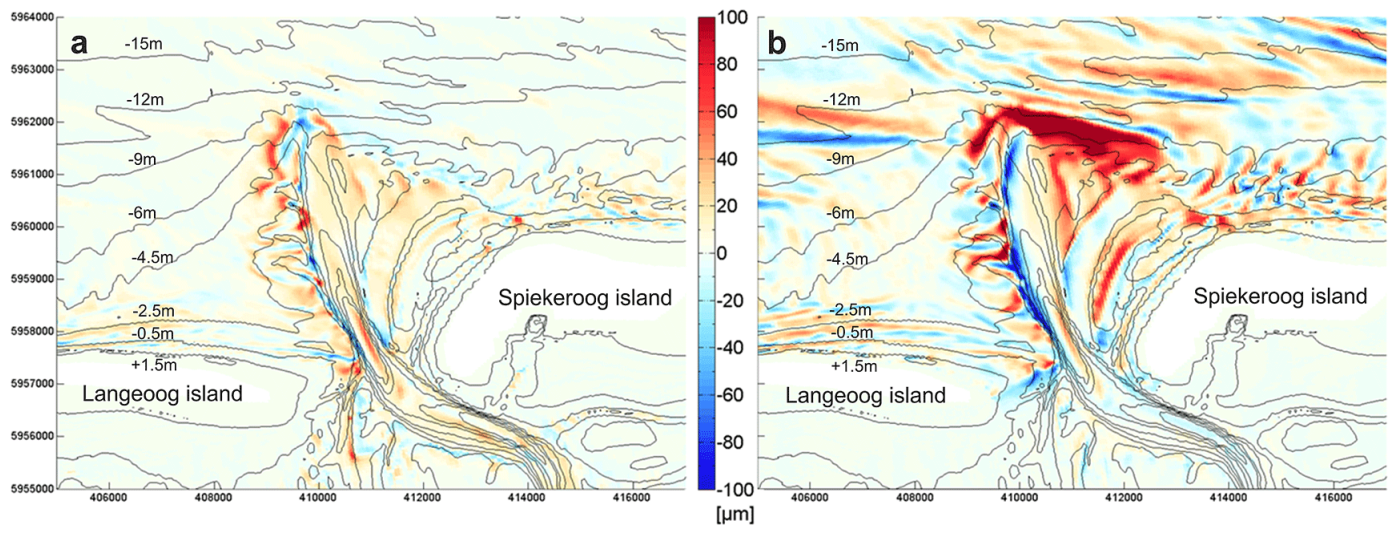

Figure 12. Sedimentological changes, i.e., relative increase (red) and decrease (blue) of mean surface sediment grain size as a response to fair-weather (a) and storm (b) conditions; analysis simulations were initiated with nonuniformly distributed sediment fractions (Fig. 4).

\section{Discussion}

\subsection{Mixed-energy tidal inlet morphology and sedimentology in response to tide- and wave-dominated conditions}

The main drivers determining the morphodynamic development of a mixed-energy tidal inlet system are commonly assumed to be waves that induce sediment stirring, transport and dispersal at the ebb-tidal delta and tidal currents in the inlet (e.g., FitzGerald et al., 2012; De Swart and Zimmerman, 2009). Mixed-energy barrier island tidal inlets are morphologically highly dynamic environments where both drivers continuously interact. Numerical model scenario experiments allow for the separation of processes and boundary conditions for greater understanding of the system. However, a potential model approach that reduces the forcing to either tides or waves alone would be misleading as the natural interaction at mixed-energy tidal inlets would be ignored. Instead, tide- and wave-dominated forcing conditions are represented here by realistic fair-weather and storm scenarios, respectively, which allow the evaluation of the morphological and sedimentological responses to distinct hydrodynamic drivers by preserving the mixed-energy regime of the system at the same time.

For typical mixed-energy tidal inlets, it is commonly assumed that ebb-tidal delta erosion during episodic storm events counteracts the continuous replenishment of the ebbtidal delta lobe during tide-dominated fair-weather conditions (FitzGerald et al., 2012; Hayes, 1979). This study reproduces and thus confirms this hypothesis: model simulations of mid-term fair-weather conditions reveal that the morphological activity mainly focuses on the inlet throat. Eastward littoral drift along the foreshore beaches supplies fine sands to the inlet throat. In the deep inlet channel, bed shear stress due to tidal currents is strong enough to remove fine sands. As residual sediment fluxes in the seaward part of the inlet throat are ebb-directed, the entrained fine sands mainly feed the ebb-tidal delta terminal lobe. During storm conditions, wave refraction and shoaling over steep bottom gradients focus wave energy towards the ebb-tidal delta lobe and its shallow shoals where energy dissipates due to wave breaking. Here, the fine sand deposited during fair-weather periods is easily mobilized and transported eastwards by the ambient flow, dominated by alongshore velocity components induced by high-energy waves. These waves, approaching at an angle with respect to the shore, generate alongshore momentum flux that is greatest in the zone of breaking waves (LonguetHiggins and Stewart, 1964). Furthermore, the model predicts transportation of coarse sand fractions as bed load in the landward direction and by migration of large swash bars superimposed onto the ebb-tidal delta shoals. As mentioned previously, the term "swash bars" is misleading as these sand bars are not primarily exposed to swash, and particularly not during storm surge conditions. Bertin et al. (2009) note a physical explanation based on a shore-directed component of forces due to wave breaking (i.e., radiation stress gradients) over the delta shoal that is not compensated for by pressure gradient terms in the momentum balance equation as the associated wave-induced water level setup is spread into the tidal inlet and the back-barrier basin; it is also referred to as the "bulldozer effect", i.e., the shoaling and prograding of the ebb-tidal delta (Hageman, 1969).

Sediment grain-size-sorting mechanisms and thus the spatial distribution of surface sediments are related to bed shear stress controlled by wave- and tide-induced flow: residual distributions of surface sediment grain sizes make it clear that both storm conditions with high-energy waves and fairweather conditions where tidal currents dominate contribute to the sedimentology of barrier island tidal inlets and foreshore. At the tidal inlet, for instance, we can generalize that winnowing of fine sand at the inlet throat and marginal channels is attributed to tidal forcing, whereas high-energy waves are the driver for sorting mechanisms at shallow shoals of the ebb-tidal delta (Fig. 3). Simulations have shown that only 
the combined scenario forcing, i.e., alternating fair-weather and storm simulations, results in a surface sediment grainsize distribution that is in fair agreement with sedimentological field observations at Otzumer Balje inlet (Fig. 7; Son et al., 2010). This suggests that the combination of both hydrodynamic forcing conditions is needed to determine the inlet sedimentology. Furthermore, in light of the analogy of modeled and observed sedimentological patterns, this confirms the model setup applied here to reliably simulate sediment dynamics in general and the evaluation of morphological and sedimentological features in response to representative boundary conditions in particular. The applied model resolution and necessarily reduced multi-fractional approach proves the ability to reproduce gradients in grain sizes on the spatial scale of morphological features equal and larger than swash bars and shore-oblique sand bars. Although smaller morphological features and bed forms such as ripples and dunes are not resolved in the model bathymetry, the modeling approach demonstrated here allows for the identification of distinct pathways of particular sediment grain-size fractions in response to wave-current interactions.

In the following, an example is given where simulated fluxes of particular sediment grain sizes combined with detailed information on three-dimensional hydrodynamics allow for the identification of larger scale sorting mechanisms at the ebb-tidal delta lobe and the upper shoreface.

Surface sediment grain-size composition reveals simulated mass fractions of up to 65 and $35 \%$ for sand fractions of 150 and $200 \mu \mathrm{m}$, respectively, which accumulate at the ebbtidal delta terminal lobe during tide-dominated fair-weather conditions. Here, predicted mean grain sizes are $170 \mu \mathrm{m}$ and thus in fair agreement with observations of 120 to $150 \mu \mathrm{m}$ at Otzumer Balje (Son et al., 2010) and 120 to $180 \mu \mathrm{m}$ at "Harle" (Hanisch, 1981), the tidal inlet to the east of Spiekeroog. The two finest sand fractions of 150 and $200 \mu \mathrm{m}$ are obviously stirred by wave action at the outer margin of the ebb-tidal delta but also bypass the inlet along the upper shoreface due to the storm-driven alongshore drift to the east. The finest fraction of $150 \mu \mathrm{m}$ primarily settles at areas of reduced energy off the downdrift island of Spiekeroog within a shore-parallel band between the surf zone and the sloping faces of the shoreface-connected ridges. Here, after the storm simulation, $20-30 \%$ of the surface sediment is made up of this finest grain-size fraction of $150 \mu \mathrm{m}$. Antia (1995) observed an almost shore-parallel elongated pattern of accumulated fine sands with mass fractions between 10 and $30 \%$ for settling velocities of $1-1.5 \mathrm{~cm} \mathrm{~s}^{-1}$, which translates to grain sizes of 115-150 $\mu \mathrm{m}$ after Gibbs et al. (1971). Antia (1995) also describes this pattern as being extended between two bands of medium sands, one at the surf zone and the other along the shoreface-connected ridges. The storm simulation reveals the physical process that explains this established deposit of fine sediments at the upper shoreface: wave-induced currents counteract the opposing westerly directed alongshore ebb-tidal currents in the expanded surf zone. The ebb- tidal flow is restricted within this zone of wave-dominated alongshore currents and shifted to deeper waters outside the surf zone. This results in a band of reduced bottom shear at the interfacial boundary area of eastwards-directed waveinduced flow and westward-directed ebb-tidal flow. In this area, settling of fine-grained sand is possible. Inside the surf zone, alongshore wave-induced bottom currents are diverted slightly offshore at a shore-oblique angle due to the opposing ebb currents. In nature, enhanced offshore-directed currents due to undertow or downwelling (e.g., Niedoroda et al., 1984) may supply additional fine sand to the zone of reduced bottom shear. The latter process is most likely underestimated by the model. The onshore-directed wave streaming (Walstra et al., 2000) opposes and reduces the offshoredirected bottom shear stresses induced by undertow that is driven by wind surge and wave setup.

Besides these deposits of fine sand at the terminal lobe of the ebb-tidal delta and the shore-parallel band at the upper shoreface, additional characteristic spatial patterns are identified that stand out due to pronounced depositional processes within the surface sediment layer. Particularly for storm conditions, the simulation reveals elongated channel fill deposits of fine-grained sand at the northern fringe of the marginal eastern flood channel, which is even more pronounced at the westerly, sloping side of the inlet throat (Figs. 11b and 12b). The latter has been classified as channel margin linear bars (Hayes, 1979). Hubbard et al. (1979) called this a "zone of equilibrium", where landward wave-induced flow over the marginal shoal platform is opposed and dominated by the ebb-directed tidal jet in the inlet throat. As described earlier, we identified several similar zones of fine-grained deposits that evidently all have in common that tidal flow is partly or fully retarded and balanced by the opposing wave-induced momentum flux or vice versa. This results in a local reduction of bottom shear along the lateral interface of counteracting current fields and supports accumulation of fine-grained sediments. Wind- and wave-induced setup increases the water depth and the cross-sectional area within the inlet, supporting further reduction of bottom shear stresses.

All other patterns at the tidal inlet and the foreshore region can be explained by erosional processes where fine sands are winnowed from surface sediments and thus medium to coarse sediment grain sizes remain, e.g., the bottom of the tidal channels during tide-dominated fair-weather conditions and the ebb-tidal delta shoals during wave-dominated storm conditions.

\subsection{Sediment recirculation patterns at the eastern ebb-tidal delta shoal}

A simulation of tidal inlet morphology, sedimentology and sediment pathways calls for the identification of the communication and coupling of mesoscale hydro- and sediment dynamics between morphological units such as the ebb-tidal delta shoals, the inlet channels and the adjacent barrier coast. 
Dissanayake et al. (2009) simulated the interaction between inlet tidal currents and alongshore tidal currents for an idealized tidal inlet by applying a process-based model. The residual flow pattern showed that a rotational current field is only developed to the east of the ebb-tidal delta. The physical description relates to the fact that strong directional velocity fields are developed to the west of the inlet when the alongshore current is eastward (westward) and the inlet current is landward (seaward), whereas the rotational current field supports the ebb-tidal delta growth in the east. These findings agree with the conceptual hypotheses of Sha (1989) and Sha and Van den Berg (1993). In a numerical model study for an idealized and a natural tidal inlet, Hench and Luettich (2003) give an additional explanation of how momentum balances contribute to circulation processes by tidal forcing alone. The inlet jet induces a "dynamical wall effect" with momentum imbalances due to tidal phase lags resulting in transient, cross-inlet elevation differences and thus secondary circulation for different stages of the tide. With respect to the symmetrical geometry of their idealized inlet, the authors were able to show that the morphology of the natural inlet, i.e., particularly marginal tidal channels, plays an additional role in focusing the identified fluxes. In contrast to these tide-controlled circulation cells, FitzGerald et al. (1976) and Smith and FitzGerald (1994) describe "sediment gyres" downdrift of the inlet due to wave refraction and swash over the ebb-tidal delta shoal platform that drive swash bars in a net landward direction, whereas waveinduced setup shoreward of the swash bars augments the inlet-directed currents in the marginal flood channel. Smith and FitzGerald (1994) conclude from sediment budgets due to assessed transport rates and morphological evolution analysis at the Essex River ebb-tidal delta system that the circulated sediment flux within the sediment gyres is estimated to be even larger than the amount that bypasses the inlet. Finley (1978) further adds that refraction of moderate waves around the inlet ebb-tidal jet is a process that contributes to ebb-tidal delta growth. The shoals are an efficient trap of reversed littoral sediment drift that would otherwise be carried alongshore.

These examples from the literature show the importance of recirculation cells for tidal inlet morphology and its budget in particular. Sediment dynamics involved are explained by physical processes that are controlled by either tides or waves. However, at mixed-energy tidal inlets, it is questionable which of the drivers contribute to the net circulation.

At the Otzumer Balje inlet, residual sediment fluxes reveal a pronounced recirculation cell at the eastern ebb-tidal delta shoal. The circular pathway of particular grain-size fractions is obviously of importance for the overall sediment dynamics. During storm conditions, individual swash bar migration and wave-induced bed load transport of medium sand point in the landward direction over the eastern ebb-delta shoal platform. During fair-weather conditions, however, residual transport is concentrated in the transverse, flood-dominated tidal channel to the south of the eastern shoal platform and leads towards the southwest into the inlet throat. Once in the inlet throat, ebb-directed residual transport directs fine and medium sand to the ebb-tidal delta, where the cycle restarts. This suggests that solely the combination of wave-dominant storm and tide-dominant fair-weather conditions leads to net sediment fluxes describing a circular pathway to the east of the tidal inlet redirecting predominantly medium sand to the inlet throat.

The simulated sediment pathways confirm the conceptual model of Son et al. (2010), who assumed a recirculation cell over the eastern ebb-tidal delta shoal of Otzumer Balje tidal inlet in which sediment is recycled towards the inlet throat. Their hypothesis was primarily derived from the orientation of sedimentary structures found in box- and vibrocores. Sediment beds showed parallel lamination, which, according to the authors, originated from storm events that are better preserved in the long term than cross-laminated features generated during moderate conditions and that indicate dominant sediment pathways of medium-grained sand in a shoreward direction over the eastern ebb-delta shoal.

Separation into wave- and tide-dominated conditions allows for the differentiation of residual sediment fluxes that contribute to the recirculation cell. First, closed sediment circulation cells are not recognized for storm conditions. Here, wave-induced bed load transport is onshore-directed over the shoal platform, but no direct reversal to the inlet throat is evident. During fair-weather conditions, a complete circulation cell is weakly identifiable with prominent residual sediment transport through the ebb-dominated inlet throat and the flood-dominated eastern marginal channel but only minor residual transport in the shoreward direction over the eastern shoal platform. Hence, we conclude that - at least for the tidal inlet studied here - significant recirculation of sand to the inlet is only possible from a combination of both fairweather and storm conditions.

In this context, we would like to address the aforementioned sediment bypass at the Otzumer Balje inlet. Son et al. (2010) suggest that there is no evidence for fine sand bypassing the tidal inlet. If at all, bypassing would take place along the subtidal margin of the terminal lobe and be independent of processes acting on the ebb-tidal delta. However, no evidence was given to support this hypothesis, as no data were collected from regions seaward of the ebbtidal delta. Our simulations reveal sediment bypass to the downdrift beach and foreshore for both moderate and extreme conditions, in disagreement with the hypothesis of Son et al. (2010). The magnitudes of the bypass, seaward extent and the dominant grain size are primarily controlled by wave energy, i.e., wave-induced alongshore currents, and are consequently increased for storm compared to fair-weather conditions.

The question of whether the net volume of sand that is recirculated to the inlet throat is dominant over the bypassed quantity must be answered by future studies, as the 
simulated scenarios are representative of either tide- or wavedominated conditions but nonrepresentative of the long-term regime of this mixed-energy tidal inlet. Ongoing research aims to elucidate the sediment budget at the tidal inlet.

\section{Conclusions}

This study identifies residual sediment fluxes of particular grain-size fractions and related morphological and sedimentological responses of a mixed-energy tidal inlet system. We use a process-based numerical modeling system to differentiate the effects of either tide- or wave-dominant forcing. During storm conditions, the ebb-tidal delta loses sand through wave impact. For fair-weather conditions, the ebb-tidal delta is replenished by ebb-directed residual sediment transports. The model simulations satisfactorily reproduce this wellknown dynamic behavior. Sediment grain-size sorting mechanisms are also affected by the interacting tide- and wavedriven flow. We have shown that only a combined scenario forcing, i.e., alternating fair-weather and storm simulations, can result in a surface sediment grain-size distribution that is in agreement with measured grain-size distributions (Son et al., 2010). Medium-sized sand is found at either tidal inlet channels exposed to tidal-flow-induced bottom shear or at the ebb-tidal delta shoals where winnowing of fine sand is a result of wave stirring. Furthermore, it is shown that surface sediments at the barrier island foreshore and the inlet system in this setting can be explained by erosional, and not depositional, processes. Morphological patterns that are prone to depositional processes and accumulation of fine sand are identified to occur in zones of reduced bottom shear as a result of opposing tidal currents and waves.
The model study confirms the significance of the recirculation of sand at this tidal inlet. Mainly medium-sized sands are redirected to the inlet throat via a semicircular pattern across the eastern ebb-tidal delta and through the easterly marginal flood tidal channel. The combination of residual sediment fluxes of both scenarios, wave-dominated storm and tidedominated fair-weather, is able to achieve this net sediment recirculation. The model shows additional sediment bypass, mainly by suspended sediment load, to the downdrift foreshore and beach, in disagreement with earlier findings of Son et al. (2010). The magnitude of the bypass, its seaward extend and the dominant grain-size fraction are primarily controlled by wave energy, i.e., wave-induced alongshore currents, and are consequently greater for storm compared to fair-weather conditions.

The overall shape of the tidal inlet of study in the German Wadden Sea appears to be similar to typical textbook tidal inlets described, for example, by Hayes (1979). Its geometry is characterized by a single ebb-dominated tidal inlet channel through the ebb-tidal delta with a slightly asymmetric outline of the shoals to the downdrift. This allows for the assumption that the processes and sediment pathway schemes discussed here are also applicable for many other mixed-energy tidal inlets within barrier island systems. This study thus reveals residual sediment transport pathways for tide- and wave-dominated conditions. It improves our understanding of complex sediment dynamics at mixed-energy tidal inlets as it identifies and qualitatively evaluates how the morphology and sedimentology respond to the contribution of distinct drivers that in nature are obscured by continuous interaction. 


\section{Appendix A:}

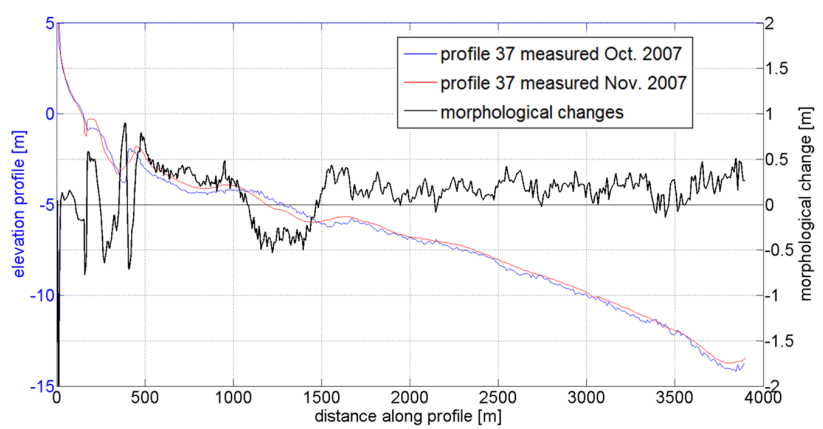

Figure A1. Elevation of cross-shore profiles at Langeoog foreshore measured in October and November 2007 and morphological changes as the response to the storm event "Tilo" (data of profile 37 with permission of the Coastal Research Station of Lower Saxony Water Management, Coastal Defense and Nature Conservation Agency, FSK-NLWKN).

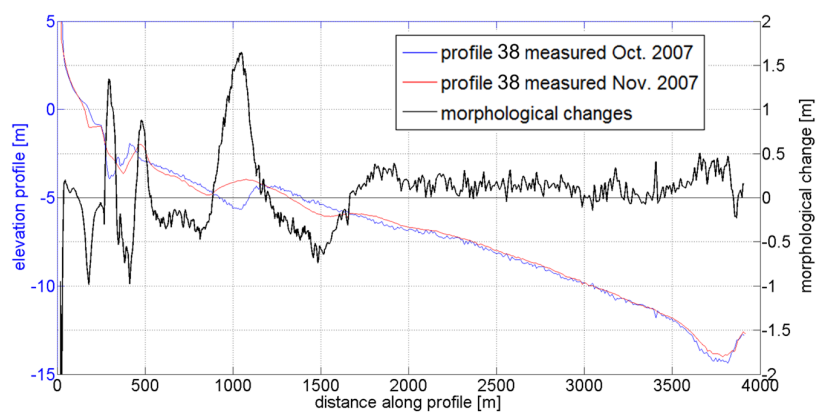

Figure A2. Elevation of cross-shore profiles at Langeoog foreshore measured in October and November 2007 and morphological changes as the response to the storm event "Tilo" (data of profile 38 with permission of the Coastal Research Station of Lower Saxony Water Management, Coastal Defense and Nature Conservation Agency, FSK-NLWKN).

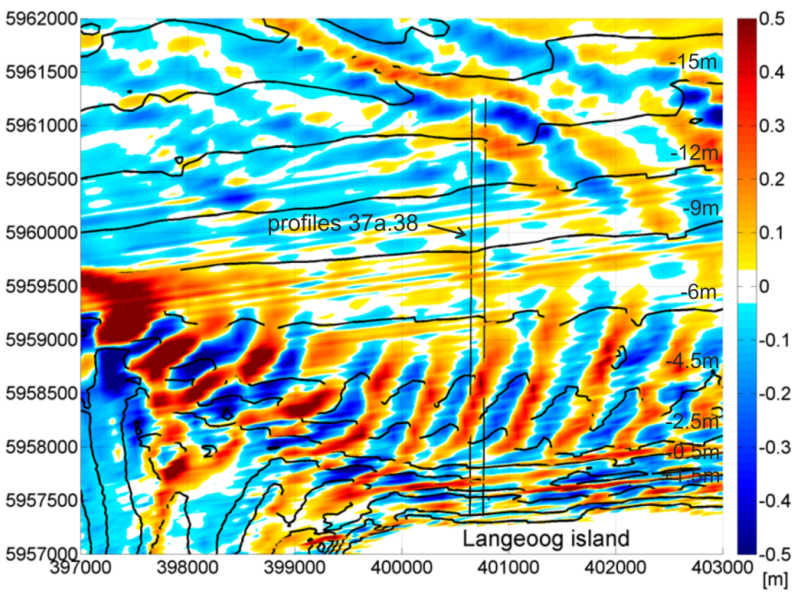

Figure A3. Morphological changes, i.e., sedimentation (red) and erosion (blue) patterns, predicted by the storm simulation at the foreshore of Langeoog with position of cross-shore profiles 37 and 38; the initial model bathymetry is based on observational data of 2006 and thus inconsistent with pre-storm cross-shore profiles of October 2007 that are shown in Figs. A1 and A2. 
Acknowledgements. This study is associated with and funded by the research project WIMO (www.wimo-nordsee.de) and is financed in equal parts by two ministries in Lower Saxony: the Ministry of Environment, Energy and Climate Protection, and the Ministry of Science and Culture.

We gratefully acknowledge the authorities and research institutes, namely the Federal Maritime and Hydrographic Agency (BSH) and the Coastal Research Station of Lower Saxony Water Management, Coastal Defense and Nature Conservation Agency (FSK-NLWKN) for furnishing bathymetrical data; the Federal Ministry for Environment, Nature Conservation and Nuclear Safety (BMU) and Project Management Jülich (PTJ) for providing measured data of waves and wind related to the research platform FINO1; the German Weather Service (DWD) for making meteorological model data available via the PAMORE database; and Senckenberg at Sea Wilhelmshaven (SaM) for furnishing in situ data of surface sediment grain size. We acknowledge the HelmholtzZentrum Geesthacht Zentrum für Material- und Küstenforschung $\mathrm{GmbH}$, notably Rolf Riethmüller and Götz Flöser, for providing wave data recorded at the back barrier of Langeoog within the framework of the Coastal Observing System for Northern and Arctic Seas (COSYNA) and for text passages in Sect. 4.1 describing their data. Many thanks go to OpenEarth.nl (DELTARES), which is at the European forefront in disseminating high-quality data, tools and models, particularly for making the Dutch Continental Shelf Model available (Verboom et al., 1992).

The authors would like to thank Mick Van der Wegen, the anonymous reviewer and the editor, Giovanni Coco, for their valuable comments and suggestions, which helped to improve the quality of this paper.

Edited by: G. Coco

\section{References}

Antia, E. E.: Sedimentary Deposits Related to Inlet-Shoreface Storm Flow Interaction in the German Bight, Estuar. Coast. Shelf Sci., 40, 699-712, doi:10.1006/ecss.1995.0047, 1995.

Ardhuin, F. and Roland, A.: The development of spectral wave models: coastal and coupled aspects, in: Proceedings of the 7th International Conference on Coastal Dynamics, 24-28 June 2013, University of Bordeaux, France, 25-38, 2013.

Ardhuin, F., Rascle, N. and Belibassakis, K. A.: Explicit wave-averaged primitive equations using a generalized Lagrangian mean, Ocean Model., 20, 35-60, doi:10.1016/j.ocemod.2007.07.001, 2008.

Badewien, T. H., Zimmer, E., Bartholomä, A., and Reuter, R.: Towards continuous long-term measurements of suspended particulate matter (SPM) in turbid coastal waters, Ocean Dynam., 59, 227-238, doi:10.1007/s10236-009-0183-8, 2009.

Bartholomä, A., Kubicki, A., Badewien, T. H., and Flemming, B. W.: Suspended sediment transport in the German Wadden Seaseasonal variations and extreme events, Ocean Dynam., 59, 213225, doi:10.1007/s10236-009-0193-6, 2009.

Bennis, A.-C., Ardhuin, F., and Dumas, F.: On the coupling of wave and three-dimensional circulation models: Choice of theoretical framework, practical implementation and adiabatic tests, Ocean Model., 40, 260-272, doi:10.1016/j.ocemod.2011.09.003, 2011.
Bertin, X., Fortunato, A. B., and Oliveira, A.: A modeling-based analysis of processes driving wave-dominated inlets, Cont. Shelf Res., 29, 819-834, doi:10.1016/j.csr.2008.12.019, 2009.

Booij, N., Ris, R. C., and Holthuijsen, L. H.: A thirdgeneration wave model for coastal regions 1 . Model description and validation, J. Geophys. Res., 104, 7649-7666, doi:10.1029/98JC02622, 1999.

Cheung, K. F., Gerritsen, F., and Cleveringa, J.: Morphodynamics and Sand Bypassing at Ameland Inlet, The Netherlands, J. Coast. Res., 231, 106-118, doi:10.2112/04-0403.1, 2007.

Cuneo, P. S. and Flemming, B. W.: Quantifying concentration and flux of suspended particulate matter through a tidal inlet of the East Frisian Wadden sea by acoustic doppler current profiling, in: Proceedings in Marine Science, Muddy Coast Dynamics and Resource Management, Elsevier, 2, 39-52, doi:10.1016/S15682692(00)80005-4, 2000.

Davis, R. Jr. and FitzGerald, D. (Eds.): Beaches and Coasts, 4th Edn., John Wiley \& Sons, Oxford, UK, 2009.

Deltares: User manual Delft-3D FLOW, online available from: www.deltares.nl (last access: December 2011), 2011.

De Swart, H. E. and Zimmerman, J. T. F.: Morphodynamics of Tidal Inlet Systems, Annu. Rev. Fluid Mech., 41, 203-229, doi:10.1146/annurev.fluid.010908.165159, 2009.

Dissanayake, D. M. P. K., Roelvink, J. A., and Van der Wegen, M.: Modelled channel patterns in a schematized tidal inlet, Coast. Eng., 56, 1069-1083, doi:10.1016/j.coastaleng.2009.08.008, 2009.

Dodet, G., Bertin, X., Bruneau, N., Fortunato, A. B., Nahon, A., and Roland, A.: Wave-current interactions in a wavedominated tidal inlet, J. Geophys. Res.-Oceans, 118, 1587-1605, doi:10.1002/jgrc.20146, 2013.

Elias, E. P. L., Cleveringa, J., Buijsman, M. C., Roelvink, J. A., and Stive, M. J. F.: Field and model data analysis of sand transport patterns in Texel Tidal inlet (The Netherlands), Coast. Eng., 53, 505-529, doi:10.1016/j.coastaleng.2005.11.006, 2006.

Elias, E. P. L. and Hansen, J. E.: Understanding processes controlling sediment transports at the mouth of a highly energetic inlet system (San Francisco Bay, CA), Mar. Geol., 345, 207-220, doi:10.1016/j.margeo.2012.07.003, 2013.

Elias, E. P. L. and Van der Spek, A. J. F.: Long-term morphodynamic evolution of Texel Inlet and its ebbtidal delta (The Netherlands), Mar. Geol., 225, 5-21, doi:10.1016/j.margeo.2005.09.008, 2006.

Elias, E. P. L., Gelfenbaum, G., and Van der Westhuysen, A. J.: Validation of a coupled wave-flow model in a high-energy setting: The mouth of the Columbia River, J. Geophys. Res.-Oceans, 117, C09011, doi:10.1029/2012JC008105, 2012.

Finley, R. J.: Ebb-tidal delta morphology and sediment supply in relation to seasonal wave energy flux, North Inlet, South Carolina, J. Sediment. Res., 48, 227-238, doi:10.1306/212F743C-2B2411D7-8648000102C1865D, 1978.

FitzGerald, D. M.: Sediment bypassing at mixed energy tidal inlets, in: Proceedings of the 18th International Conference on Coastal Engineering, 14-19 November 1982, Cape Town, South Africa, 1094-1118, 1982.

FitzGerald, D. M., Nummedal, D., and Kana, T. W.: Sand circulation pattern at Price Inlet, South Carolina, in: 15th Conference on Coastal Engineering, Honolulu, Hawaii, 1976. 
FitzGerald, D. M., Penland, S., and Nummedal, D. A. G.: Control of barrier island shape by inlet sediment bypassing: East Frisian Islands, West Germany, Develop. Sediment., 39, 355376, doi:10.1016/S0070-4571(08)70154-7, 1984.

FitzGerald, D. M., Buynevich, I., and Hein, C.: Morphodynamics and Facies Architecture of Tidal Inlets and Tidal Deltas, in: Principles of Tidal Sedimentology SE 12, edited by: Davis Jr., R. A. and Dalrymple, R. W., Springer, Netherlands, 301-333, 2012.

Fredsøe, J.: Turbulent boundary layer in wave-current motion, J. Hydraul. Eng., 110, 1103-1120, 1984.

Gibbs, R. J., Matthews, M. D., and Link, D. A.: The relationship between sphere size and settling velocity, J. Sediment. Res., 41, 7-18, doi:10.1306/74D721D0-2B21-11D78648000102C1865D, 1971.

Hageman, B. P.: Development of the western part of the Netherlands during the Holocene, Geol. en Mijnb., 48, 373-388, 1969.

Hanisch, J.: Sand transport in the tidal inlet between Wangerooge and Spiekeroog (W. Germany), Holocene Mar. Sediment. North Sea Basin Spec. Publ. 5, IAS, 35, 175-185, 1981.

Hayes, M. O.: Morphology of sand accumulation in estuaries: an introduction to the symposium, edited by: Cronin, L. E., Estuar. Res., 2, 3-22, 1975.

Hayes, M. O.: Barrier island morphology as a function of tidal and wave regime, in: Barrier islands, from the Gulf of St. Lawrence to the Gulf of Mexico, edited by: Leatherman, S., Academic Press, New York, 1-27, 1979.

Hench, J. L. and Luettich, R. A.: Transient Tidal Circulation and Momentum Balances at a Shallow Inlet, J. Phys. Oceanogr., 33, 913-932, 2003.

Hubbard, D. K., Oertel, G., and Nummedal, D.: The role of waves and tidal currents in the development of tidal-inlet sedimentary structures and sand body geometry; examples from North Carolina, South Carolina, and Georgia, J. Sediment. Res., 49, 1073-1091, doi:10.1306/212F78B5-2B24-11D78648000102C1865D, 1979.

Isobe, M. and Horikawa, K.: Study on water particle velocities of shoaling and breaking waves, Coastal Engineering in Japan, 25, 109-123, 1982.

Kaiser, R., Niemeyer, H. D., Dirks, H., and Witting, M.: KFKIProjekt DÜNEROS, Schlussbericht 03KIS063, Norderney, 2008.

Komar, P. D.: Tidal-Inlet Processes and Morphology Related to the Transport of Sediments, J. Coast. Res., 23, 23-45, 1996.

Kwoll, E. and Winter, C.: Determination of the initial grain size distribution in a tidal inlet by means of numerical modelling, $\mathrm{J}$. Coast. Res., 64, 1081-1085, 2011.

Lane, A., Riethmuller, R., Herbers, D., Rybaczok, P., Gunther, H., Baumert, H., and Riethmüller, R.: Observational data sets for model development, Coast. Eng., 41, 125-153, doi:10.1016/S0378-3839(00)00029-6, 2000.

Lesser, G. R., Roelvink, J. A., van Kester, J. A. T. M., and Stelling, G. S.: Development and validation of a threedimensional morphological model, Coast. Eng., 51, 883-915, doi:10.1016/j.coastaleng.2004.07.014, 2004.

Longuet-Higgins, M. S. and Stewart, R. W.: Radiation stresses in water waves; a physical discussion, with applications, Deep-Sea Res., 11, 529-562, 1964.

Nahon, A., Bertin, X., Fortunato, A. B., and Oliveira, A.: Processbased 2DH morphodynamic modeling of tidal inlets: A compar- ison with empirical classifications and theories, Mar. Geol., 291, 1-11, doi:10.1016/j.margeo.2011.10.001, 2012.

Niedoroda, A. W., Swift, D. J. P., Hopkins, T. S., and Ma, C.M.: Shoreface morphodynamics on wave-dominated coasts, Mar. Geol., 60, 331-354, doi:10.1016/0025-3227(84)90156-7, 1984.

Noormets, R., Ernstsen, V. B., Bartholomä, A., Flemming, B. W., and Hebbeln, D.: Implications of bedform dimensions for the prediction of local scour in tidal inlets: a case study from the southern North Sea, Geo-Mar. Lett., 26, 165-176, doi:10.1007/s00367-006-0029-z, 2006.

Onken, R., Callies, U., Vaessen, B., and Riethmüller, R.: Indirect determination of the heat budget of tidal flats, Cont. Shelf Res., 27, 1656-1676, doi:10.1016/j.csr.2007.01.029, 2007.

Outzen, O., Herklotz, K., Heinrich, H., and Lefebvre, C: Extreme waves at FINO 1 research platform caused by storm 'Tilo' on 9 November 2007, DEWI Mag., 33, 17-23, 2008.

Ris, R. C., Holthuijsen, L. H., and Booij, N.: A third-generation wave model for coastal regions 2. Verification, J. Geophys. Res., 104, 7667-7681, doi:10.1029/1998JC900123, 1999.

Rodi, W.: Turbulence models and their application in hydraulics, a state of the art review, International Association of Hydraulics Research, Delft, the Netherlands, 1984.

Roelvink, J. A.: Coastal morphodynamic evolution techniques, Coast. Eng., 53, 277-287, doi:10.1016/j.coastaleng.2005.10.015, 2006.

Schneggenburger, C., Günther, H., and Rosenthal, W.: Spectral wave modelling with non-linear dissipation: Validation and applications in a coastal tidal environment, Coast. Eng., 41, 201235, doi:10.1016/S0378-3839(00)00033-8, 2000.

Sha, L. P.: Variation in ebb-delta morphologies along the West and East Frisian Islands, The Netherlands and Germany, Mar. Geol., 89, 11-28, doi:10.1016/0025-3227(89)90025-X, 1989.

Sha, L. P.: Surface sediments and sequence models in the ebb-tidal delta of Texel Inlet, Wadden Sea, The Netherlands, Sediment. Geol., 68, 125-141, doi:10.1016/0037-0738(90)90123-B, 1990.

Sha, L. P. and Van Den Berg, J. H.: Variation in Ebb-Tidal Delta Geometry along the Coast of the Netherlands and the German Bight, J. Coast. Res., 9, 730-746, 1993.

Smith, J. B. and FitzGerald, D. M.: Sediment Transport Patterns at the Essex River Inlet Ebb-Tidal Delta, Massachusetts, USA, J. Coast. Res., 10, 752-774, 1994.

Son, C. S., Flemming, B. W., and Bartholomä, A.: Evidence for sediment recirculation on an ebb-tidal delta of the East Frisian barrier-island system, southern North Sea, Geo-Mar. Lett., 31, 87-100, doi:10.1007/s00367-010-0217-8, 2010.

Soulsby, R. L., Hamm, L., Klopman, G., Myrhaug, D., Simons, R. R., and Thomas, G. P.: Wave-current interaction within and outside the bottom boundary layer, Coast. Eng., 21, 41-69, 1993.

Van der Wegen, M. and Roelvink, J. A.: Reproduction of estuarine bathymetry by means of a process-based model: Western Scheldt case study, the Netherlands, Geomorphology, 179, 152167, doi:10.1016/j.geomorph.2012.08.007, 2012.

Van der Wegen, M., Dastgheib, A., Jaffe, B. E., and Roelvink, D.: Bed composition generation for morphodynamic modeling: case study of San Pablo Bay in California, USA, Ocean Dynam., 61, 173-186, doi:10.1007/s10236-010-0314-2, 2011 a.

Van der Wegen, M., Jaffe, B. E., and Roelvink, J. A.: Process-based, morphodynamic hindcast of decadal deposition patterns in San 
Pablo Bay, California, 1856-1887, J. Geophys. Res.-Earth, 116, F02008, doi:10.1029/2009JF001614, 2011b.

Van der Westhuysen, A. J.: Advances in the spectral modelling of wind waves in the nearshore, Delft University of Technology, Delft, the Netherlands, 207 pp., 2007.

Van der Westhuysen, A. J.: Spectral modeling of wave dissipation on negative current gradients, Coast. Eng., 68, 17-30, doi:10.1016/j.coastaleng.2012.05.001, 2012.

Van Lancker, V., Lanckneus, J., Hearn, S., Hoekstra, P., Levoy, F., Miles, J., Moerkerke, G., Monfort, O., and Whitehouse, R.: Coastal and nearshore morphology, bedforms and sediment transport pathways at Teignmouth (UK), Cont. Shelf Res., 24, 1171-1202, doi:10.1016/j.csr.2004.03.003, 2004.

Van Rijn, L. C.: Principles of sediment transport in rivers, estuaries and coastal seas, Aqua publications, Amsterdam, the Netherlands, 1993.

Van Rijn, L. C.: General view on sand transport by currents and waves: data analysis and engineering modelling for uniform and graded sand, Report Z28, Deltares (WL), Delft, the Netherlands, 2000 .
Van Rijn, L. C.: Sand transport by currents and waves; general approximation formulae, in: Proceedings of the International Conference on Coastal Sediments, 18-23 May 2003, Clearwater Beach, Florida, USA, vol. 3, 2003.

Van Rijn, L. C., Walstra, D. J. R., and Van Ormondt, M.: Description of TRANSPOR2004 and implementation in Delft3D-ONLINE, Interim Rep. Prep. DG Rijkswaterstaat, Rijksinst, voor Kust en Zee, Delft Hydraul. Institute, Delft, the Netherlands, 2004.

Verboom, G. K., de Ronde, J. G., and van Dijk, R. P.: A fine grid tidal flow and storm surge model of the North Sea, Cont. Shelf Res., 12, 213-233, doi:10.1016/0278-4343(92)90030-N, 1992.

Walstra, D. J. R., Roelvink, J. A., and Groeneweg, J.: Calculation of Wave-Driven Currents in a 3D Mean Flow Model, in: Coastal Engineering, American Society of Civil Engineers, Reston, VA, 1050-1063, 2000. 